\title{
Decisionmaking Models and the Control of Corporate Crime
}

The complexity of modern corporate decisionmaking tends both to obscure and to diffuse responsibility for corporate actions. Thus, efforts to deter corporate crime ${ }^{1}$ have been frustrated by difficulties in identifying the lawbreakers and in determining appropriate grounds for liability. ${ }^{2}$ Set against this background of frustration, the recent expressions of concern by Congress, ${ }^{3}$ the Department of Justice, ${ }^{4}$ and

1. This Note focuses on certain federal criminal violations by corporate entities and employees-violations perpetrated to advance the interest of the corporate entity. Such violations, the immediate objective of which is organizational rather than personal gain, have been termed "acquisitive corporate crime" by Professor Dershowitz. Comment, Increasing Community Control Over Corporate Crime-A Problem in the Law of Sanctions, 71 YALE L.J. 280, 281 (1961). This definition does not exclude violations by employees who believe that they ultimately will benefit through advancement of the corporate interest.

2. See, e.g., H. Pepinsky, Crime and Conflict 134-39 (1976); C. Stone, Where the Law Ends: The Social Control of Corforate Behavion 58-63 (1975); Comment, The Criminal Responsibility of Corporate Officials for Pollution of the Environment, 37 ALB. L. REV. 61, 70-71 (1972); Hearings on Reform of the Federal Criminal Laws Before the Subcomm. on Criminal Laws and Procedures of the Senate Comm. on the Judiciary, 92d Cong., 2d Sess., pt. III, subpt. B, 1663-75 (Alan Ruben, Cleveland-Marshall College of Law) (1972) [hereinafter cited as 1972 Hearings]; id., subpt. D, 2991-3012 (Ralph Nader). The same difficulties were noted nearly a decade ago in President's Commission on Law Enforciment and administration of Justice, Task force Report: Crime and ITS IMPACT-AN AssESSMENT 106, 110 (1967).

3. Congress has stressed the need for more effective control of corporate crime throughout its 10-year effort to revise Title is of the United States Code. S. 1, 94th Cong., 1st Sess. (1975), is the offspring of exhaustive study by a congressionally established commission, cxtensive proposals by the Nixon Administration, and three years of Senate committee hearings. See 1 Working Papcrs of the National Commission on Reform of Fedrral Criminal Laws 163-215 (1970) [hereinafter cited as Working Papers]; Final Report of the National Commission on Reform of Federal Criminal Laws (1971) [hereinafter cited as FINAL RePORT]; 1972 Hearings, supra note 2, at pt. III, subpts. B, D; Hearings on Reform of the Federal Criminal Laws Before the Subcomm. on Criminal Laws and Procedures of the Senate Comm. on the Judiciary, 93d Cong., $2 \mathrm{~d}$ Sess., pts. X, $\mathrm{XI}$ (1974) [hereinafter cited as 1974 Hearings]. Because of controversy surrounding various sections of the bill, it has become mired in the Senate Judiciary Committec.

Awaiting resolution of the stalemate over $S$. I are three House bills. The two most recently introduced mirror $S$. $I$ in their treatment of corporate entities and employees. Compare S. 1 with H.R. 10850, 94th Cong., Ist Sess. (1975), and H.R. 3907, 94th Cong., lst Sess. (1975). This may signal that a congressional consensus on corporate criminal law has developed since the introduction of a House bill with dissimilar provisions concerning entity liability. H.R. 333, 94th Cong., 1st Sess. (1975). Three of the four sponsors of H.R. 333 also are the sponsors of H.R. 10850 .

The substance of the Senate and House bills is discussed further at note 8 infra.

4. The Attorney General has appointed a departmental committee to study and recommend means of more effectively combating white-collar crime, including corporate offenses. N.X. Times, October 14, 1975, at 1, col. 2. 
the Supreme Court ${ }^{5}$ suggest that legal policy with respect to corporate crime may be entering a period of transformation.

This Note argues that effective legal policy concerning corporate crime must be founded on an understanding of the decisionmaking process underlying corporate action. With this understanding, legal policymakers-legislators, prosecutors, and judges-can impose criminal penalties on those decisionmakers most capable of preventing corporate lawbreaking. As a result, those who shape the corporate decisionmaking process will be encouraged to do so in a way that enhances the likelihood of law-abiding corporate conduct.

The Note proceeds by analyzing different characterizations of the corporate decisionmaking process and exploring their implications for the development of appropriate legal policy. ${ }^{6}$ The analysis is structured by three widely used models of decisionmaking, each of which isolates and illuminates distinctive facets of the decisionmaking process. These models have been most thoroughly and rigorously articulated by Graham Allison in explaining the foreign policies of governments. ${ }^{7}$ In this Note the models are employed to elucidate how corporate lawbreaking takes place and how it may be controlled.

\section{Shortcomings of Current Federal Law: Entity and Employee Liability for Corporate Crime}

The liability of corporate entities and employees for lawbreaking to advance the interest of the corporation is not defined by any one federal statute. ${ }^{8}$ Rather, corporate criminal law is a pastiche of regula-

5. See United States v. Park, 421 U.S. 658, 673 (1975).

6. Although this Note concentrates on the implications of the models for legislators, prosecutors, and judges, those implications are of importance for other legal policymakers as well. For example, a regulatory agency such as the Food and Drug Administration might consider them in performing its rulemaking, investigatory, or prosecutorial functions.

7. G. Allison, Essence of Decision: Explaining the Cuban Missile Crisis (1971).

8. Each of the bills now before Congress, described at note 3 supra, tries to fill this gap by including general provisions defining entity liability (S. 1, $\S 402$; H.R. 10850, $\S 403$; H.R. 3907, $\S 402 ;$ H.R. 333, $\S 402$ ) and employee liability (S. 1, $\S 403$; H.R. 10850, $\S 404 ;$ H.R. $3907, \S 403$; H.R. 333, $\$ 403$ ). The language of H.R. 333 differs substantially with respect to entity liability and slightly with respect to employee liability. The other two House bills track the language of S. 1:

$\$ 402$. Liability of an Organization for Conduct of an Agent

An organization is criminally liable for an offense if the conduct constituting the offense, in whole or in part:

(a) is conduct of its agent, and such conduct:

(1) occurs in the performance of matters within the scope of the agent's employment or within the scope of the agent's actual, implied, or apparent authority; or

(2) is thereafter ratified or adopted by the organization; or

(b) involves a failure by the organization or its agent to discharge a specific duty of conduct imposed on the organization by law. 
tory statutes, judicial interpretations of vague legislative mandates, and adaptations of civil liability rules. ${ }^{9}$

Statutory provisions expressly imposing criminal liability on corporate entities are scattered throughout the United States Code. ${ }^{10}$ Where a statute does not expressly apply to corporations, entity liability may still be authorized. Title $1, \S 1$ of the United States Code provides that in acts of Congress the words "person" and "whoever" include corporations "unless the context indicates otherwise." 11 Furthermore, the Supreme Court has long held that if the problems the legislature intended to reach through a regulatory statute are as likely to involve corporations as natural persons, the words "any person" in the statute's penal clause can be construed to include corporate entities. ${ }^{12}$

\section{\$ 403. Liability of an Agent for Conduct of an Organization}

(a) Conduct on Behalf of Organization.-A person is criminally liable for an offense based upon conduct that he engages in or causes in the name of an organization or on bchalf of an organization to the same extent as if he engaged in or caused the conduct in his own name or on his own behalf.

(b) Omission to Perform Duty of Organization.-Except as otherwise expressly provided, whenever a duty to act is imposed upon an organization by a statute, or by a regulation, rule, or order issued pursuant thereto, an agent of the organization having significant responsibility for the subject matter of the duty is criminally liable for an offense based upon an omission to perform the duty, if he has the state of mind required for the commission of the offense, to the same extent as if the duty were imposed upon him directly.

(c) Reckless Default in Supervising Conduct of Organization.-A person responsible for supervising particular activities on behalf of an organization who, by his reckless default in supervising those activities, permits or contributes to the commission of an offense by the organization, is criminally liable for the offense ....

Much of this language simply codifies principles of entity and employee liability articulated in case law, though the proposed text does depart from present law in some respects. See notes $14,19,23,31,34,66,119$ \& 123 infra.

9. For a comprehensive discussion of the criminal liability of corporate entities and employees under present federal law, see Working PAPERs, supra note 3, at 167-81, 207-13.

10. Many statutes both within and outside Title 18 apply their prohibitions directly to corporate entities. E.g., Federal Election Campaign Act, 2 U.S.C.A. $\$ 441$ b (Sept. 1976 Pamphlet) (corporation expressly prohibited from making federal campaign contributions or expenditures); 18 U.S.C. $\$ 402$ (1970) (corporation expressly liable for criminal contempt); $i d . \$ \$ 831, \$ 32$ (corporation expressly included as "person" liable for violations involving transportation of explosives and other dangerous articles); 21 U.S.C. $\$ 610$ (1970) (corporation expressly directed to comply with regulations for the preparation, sale, transportation, and preservation of meat and meat products); 33 U.S.C. $\$ \$ 1001(f)$, 1002, 1003 (1970 \& Supp. IV 1974) (corporation expressly included as "person" prohibited from discharging oil in coastal seas except under certain circumstances).

Other statutes provide that an act, omission, or failure of any official, agent, or other person acting for an artificial entity within the scope of his employment shall be deemed the act, omission, or failure of the entity as well as of the individual. E.g., 7 U.S.C. $\$ 87 \mathrm{~d}$ (1970) (maintenance of grain standards); 21 U.S.C. $\$ 461$ (a) (1970) (regulation of poultry production, transportation, and salc); 49 U.S.C. $\$ 41(2)$ (1970) (regulation of common carriers or shippers).

11. I U.S.C. $\$ 1(1970)$.

12. United States v. Union Supply Co., 215 U.S. 50, 54-55 (1909) (rejecting argument that since statute imposed as penalty both fine and imprisonment for each violation, it could not have contemplated corporate liability).

A similar issue of statutory construction recently arose with respect to the Water 
Because of the imprecision of statutory language, ${ }^{13}$ the courts rather than Congress have been primarily responsible for delimiting the circumstances under which corporate entities are criminally liable. The judicial consensus is that corporations are liable for acts of employees which constitute or cause criminal offenses if such acts are done on behalf of the entity and are within the scope of the actor's authority.14 The "employees" for whose acts the corporate entity is penalized are commonly executive or managerial officials, ${ }^{15}$ but the status of the lawbreaking employee in the organizational hierarchy is irrelevant to entity liability. ${ }^{16}$ Lawbreaking acts "on behalf of" the

Pollution Control Act Amendments of 1972, \$ 311(b)(5), 33 U.S.C. \$ 1321(b)(5) (Supp. IV 1974). See United States v. Hougland Barge Line, Inc., 387 F. Supp. 1110 (W.D. Pa. 1974) (term "person in charge," as used in Act's provision requiring any person in charge of vessel to notify U.S. Coast Guard "as soon as he has knowledge of any discharge of oil" from vessel in violation of Act, construed to include corporation).

13. A statute imposing corporate liability is inherently imprecise because it attributes criminal acts to an inert entity rather than or in addition to the employees who actually performed them. For example, it is not clear how a corporation as an entity can bribe a meat inspector, as prohibited by 21 U.S.C. $\$ 622$ (1970). Some statutes pose additional problems because of the vagueness of the acts they prohibit. See, e.g., 15 U.S.C. $\$ 1263$ (a) (1970) (prohibiting "introduction" into interstate commerce of misbranded or banned hazardous substances).

14. See, e.g., United States v. American Radiator \& Standard Sanitary Corp., 433 F.2d 174, 204-05 (3d Cir. 1970), cert. denied, 401 U.S. 948 (1971); United States v, Carter, 311 F.2d 934, 942 (6th Cir.), cert. denied, 373 U.S. 915 (1963); Egan v. United States, 137 F.2d 369,379 (8th Cir.), cert. denied, 320 U.S. 788 (1943).

The drafters of S. 1, 94th Cong., 1st Sess. (1975), may have intended $\$ 402(a)$ of the bill, quoted at note 8 supra, to codify this judicial consensus. But in fact liability under $S .1$ is defined more broadly. Section $402(a)(1)$ would make an entity liable for actions by an employee within the scope of his authority or within the scone of his employment. Courts have often used the latter phrase in the same sense as "on behalf of the entity." See, e.g., United States v. Hilton Hotels Corp., 467 F.2d 1000, 1006 n.4 (9th Cir. 1972), cert. denied, 409 U.S. 1125 (1973); Standard Oil Co. v. United States, 307 F.2d 120, 125 (5th Cir. 1962). If the legislative usage follows the judicial, the section would seem to transform these two elements of entity liability into alternative bases for it. Section 402(a)(2), which would make an entity liable for lawbreaking conduct ratified by the corporation, is more traditional, in that ratification not only provides post hoc authorization for the employee's actions but also signifies that he acted for the benefit of the entity.

15. E.g., United States v. American Radiator \& Standard Sanitary Corp., 433 F.2d 174, 180 (3d Cir. 1970), cert. denied, 401 U.S. 948 (1971) (corporations liable for price-fixing conspiracy by their presidents, vice presidents, and other executives); United States v. Carter, 311 F.2d 934, 942-43 (6th Cir.), cert. denied, 373 U.S. 915 (1963) (corporation liable for president's unlawful payment to union representative); Magnolia Motor \& Logging Co. v. United States, 264 F.2d 950, 953-54 (9th Cir.), cert. denied, 361 U.S. 815 (1959) (corporation liable for president's theft and conversion of government property); United States v. Milton Mark's Corp., 240 F.2d 838, 839-40 (3d Cir. 1957) (corporation liable for general foreman's instructions to include defective cartridge clips in boxes sold to government); C.I.T. Corp. v. United States, 150 F.2d 85, 88 (9th Cir. 1945) (corporation liable for conspiracy among area managers to make falsified credit applications).

16. E.g., United States v. Chicago Express, Inc., 273 F.2d 751, 753 (7th Cir. 1960) (corporation liable for driver's failure to placard truck whose load he kncw was dangerous); United States v. George F. Fish, Inc., 154 F.2d 798, 801 (2d Cir.), cert. denied, 323 U.S. 869 (1946) (corporation liable for salesman's willful violation of pricc controls: "No distinctions are made . . . between persons holding positions involving varying degrees of 
corporation are those of which the entity was the intended beneficiary: if the employee acted for his own personal benefit or for that of another, the entity is not criminally responsible. ${ }^{17}$ However, so long as the entity was the intended beneficiary, it does not matter whether the employee's actions actually had a beneficial effect. ${ }^{18}$ The "scope of authority" within which an employee's criminal conduct may become the basis for entity liability is quite broad: courts have rejected corporate defenses that employees acted beyond their official authority ${ }^{19}$ and that the unlawful conduct had been specifically forbidden by corporate superiors. ${ }^{20}$

Judicial opinions describing a corporation's criminal liability frequently allude to tort concepts. ${ }^{21}$ Building on principles of civil

responsibility.") But see United States v. United States Cartridge Co., 198 F.2d 456, 46465 (8th Cir. 1952), cert. denied, 345 U.S. 910 (1953) (under special wartime circumstances, munitions manufacturer permitted to exempt itself contractually from liability for illegal acts of nonsupervisory personnel).

17. E.g., United States v. Ridglea State Bank, 357 F.2d 495, 498-500 (5th Cir. 1966) (defendant corporation not liable for employee's approval of fraudulent loan applications where sole purpose was personal gain);- Standard Oil Co. v. United States, 307 F.2d 120, 128-29 (5th Cir. 1962) (defendant corporation not liable for illegal oil sales by employees actually working for third party).

18. E.g., United States v. Carter, 311 F.2d 934, 942 (6th Cir.), cert. denied, 373 U.S. 915 (1963); United States v. Empire Packing Co., 174 F.2d 16, 20 (7th Cir.), cert. denied, 337 U.S. 959 (1949); Old Monastery Co. v. United States, 147 F.2d 905, 908 (4th Cir.), cert. denied, 326 U.S. 734 (1945).

19. E.g., United States v. American Radiator \& Standard Sanitary Corp., 433 F.2d 174, 204-05 (3d Cir. 1970), cert. denied, 401 U.S. 948 (1971) (approving jury instruction that corporation could be found criminally liable for conduct of employee acting within scope of his "apparent authority"); Continental Baking Co. v. United States, 281 F.2d 137, 150.51 (6th Cir. 1960) (approving jury instruction that corporation is legally responsible for criminal acts within scope of an employce's "express or apparent authority"). S. 1, 94th Cong., lst Sess. $\$ 402(a)(1)(1975)$, quoted at note 8 supra, provides that an entity shall be liable for conduct "within the scope of the agent's actual, implied, or apparent authority."

20. E.g., United States v. Hilton Hotels Corp., 467 F.2d 1000, 1006-07 (9th Cir. 1972), cert. denied, 409 U.S. 1125 (1973) (corporation liable for Sherman Act violation of purchasing agent who disregarded specific instructions of local hotel manager); United States v. Harry L. Young \& Sons, 464 F.2d 1295, 1296-97 (10th Cir. 1972) (corporation liable for violation of ICC regulation by truck driver who disregarded specific instructions of local dispatcher); United States v. Armour \&. Co., 168 F.2d 342, 343-44 (3d Cir. 1948) (corporation liable for violations of price control regulations by salesmen who disregarded oral instructions of branch managers based on written directives from home office). See Note, Corporate Criminal Liability for Acts in Violation of Company Policy, 50 GLo. L.J. 547, 557-58 (1962).

21. E.g., United States v. A \& P Trucking Co., 358 U.S. 121, 125 (1958) ("[I]t is clementary that [corporations and other associations] can be guilty of 'knowing' or 'willful' violations of regulatory statutes through the doctrine of respondeat superior."); Standard Oil Co. v. United States, 307 F.2d 120, 127 (5th Cir. 1962) (That corporations are responsible for their agents' actions is "a part of the law of respondeat superior and accepted as [an] established [principle] in civil tort situations.") The reliance on rules of tort liability to justify holding corporations criminally accountable traces its ancestry to the Supreme Court's opinion in New York Cent. \& H.R.R.R. v. United States, 212 U.S. 481, 494 (1909). There the Court sought to minimize the import of its first approval of entity liability for a criminal offense by contending that it was going "only a step" beyond accepted principles of civil liability. 
liability, courts have penalized entities for crimes which require willfulness and knowledge $e^{22}$ as well as for those for which strict liability is imposed, ${ }^{23}$ and for conspiracies ${ }^{24}$ as well as for substantive offenses. ${ }^{25}$ Unfortunately, the tort analogy may be a misleading guide for determining entity liability. Such an analogy overlooks the different policy considerations underlying criminal and civil penalties. In particular, although both criminal and civil law are concerned with deterring undesirable conduct, only the latter is also concerned with compensating injured parties. ${ }^{26}$ Under certain circumstances, the compensation rationale for damage awards may dictate entity liability though employee liability may be preferable on deterrence grounds. Thus, the tort analogy does not offer a wholly satisfactory answer to the basic question of when entities should be held criminally responsible.

Problems in defining criminal responsibility also pervade statutory and case law concerning corporate employees. Unquestionably, employees may be criminally liable for corporate offenses in which they have been involved. ${ }^{27}$ However, neither Congress nor the courts have

22. E.g., Boise Dodge, Inc. v. United States, 406 F.2d 771, 772 (9th Cir. 1969) (removal of automobile manufacturer's labels); Steere Tank Lines, Inc. v. United States, 330 F.2d 719, 721-22 (5th Cir. 1963) (falsification of drivers' logs); Magnolia Motor \& Logging Co. v. United States, 264 F.2d 950, 953-54 (9th Cir.), cert. denied, 361 U.S. 815 (1959) (theft and conversion of government property).

23. Although normally associated with tort law, the term "strict liability" is cmployed in discussions of corporate crime as well. See, e.g., Working PAPERs, supra note 3, at 189-91. The Federal Food, Drug, and Cosmetic Act, 21 U.S.C. $\$ 331$ (1970 \& Supp. IV 1974), is typical of public welfare statutes that hold corporations strictly liable for crim. inal violations. See, e.g., United States v. Wiesenfeld Warehouse Co., 376 U.S. 86, 91 (1964); United States v. Parfait Powder Puff Co., 163 F.2d 1008, 1009 (7th Cir. 1917), cert. denied, 332 U.S. 851 (1948).

S. 1, 94th Cong., 1st Sess. $\$ 402$ (b) (1975), quoted at note 8 supra, would authorize entity liability for failure to "discharge a specific duty of conduct imposed on the organization by law." Since there is no requirement that the duty of conduct be imposed by statutory law, this provision would encourage the continued importation into criminal law of duties arising from the common law of torts.

24. E.g., United States v. American Radiator \& Standard Sanitary Corp., 433 F.2d 174, 180-81, 204-05 (3d Cir. 1970), cert. denied, 401 U.S. 948 (1971) (conspiracy to fix prices in plumbing supplies industry); C.I.T. Corp. v. United States, 150 F.2d 85, 87, 89.90 (9th Cir. 1945) (conspiracy to make falsified credit applications); Egan v. United States, 137 F.2d 369, 372, 379-80 (8th Cir.), cert. denied, 320 U.S. 788 (1943) (conspiracy to make corporate political contributions).

25. E.g., United States v. A \& P Trucking Co., 358 U.S. 121, 125 (1958); cases citcd note 22 supra.

26. See Working Papers, supra note 3 , at 184 n.64.

27. Indeed, a corporate offense for which the entity is criminally liable is almost invariably one for which employees are also liable. But see Sherman v. United States, 282 U.S. 25, 29-30 (1930) (several sections of Safety Appliance Acts, 45 U.S.C. $\$ \$ 1-16$ (1970), impose liability solely on common carrier itself); cf. United States v. Memphis Retail Package Stores Ass'n, 334 F. Supp. 686, 689-90 (W.D. Tenn. 1971) (where, pursuant to antitrust conviction of his corporation and himself, corporate president had paid own 
stated clearly what status in the organization and what degree of involvement are necessary to sustain individual criminal liability. With the rare exception of a provision declaring specific officials liable for corporate violations, ${ }^{28}$ statutes typically authorize criminal sanctions for individuals designated variously as "officers," "directors," "managers," "agents," or "employees." 29 But even provisions that do not mention certain of these individuals may be the basis for imposing liability on them: the Supreme Court has held that if a statute does not expressly exclude such liability, those who have a "responsible share" in a proscribed transaction on behalf of the corporation are subject to the statutory penalties. ${ }^{30}$

Such a holding, however, begs the critical question, for the courts have failed to delimit precisely the "responsibility" of corporate em-

criminal fine and discharged duties in good faith, he was not liable for nonpayment of corporation's fine).

Despite the common liability of entities and employees and the truism that corporations cannot act except through their employees, the joint trial of an entity and its employees for a given offense frequently leads to inconsistent verdicts: juries often convict the corporation but acquit the individuals. See, e.g., Magnolia Motor \& Logging Co. v. United States, 264 F.2d 950, 953-54 (9th Cir.), cert. denied, 361 U.S. 815 (1959); Southern Advance Bag \& Paper Co. v. United States, 133 F.2d 449, 450-51 (5th Cir. 1943); American Medical Ass'n v. United States, 130 F.2d 233, 252-53 (D.C. Cir. 1942), aff'd, 317 U.S. 519 (1913); Comment, supra note 1, at $292-93$ n.50. But see United States v. Dotterweich, 320 U.S. 277, 279 (1913) (upholding conviction of corporate president by jury that acquitted his corporation of same offense).

Though courts have never overturned entity convictions solely because of employee acquittals, inconsistent verdicts of this sort have disturbed the appellate bench. See, e.g., Pevely Dairy Co. v. United States, 178 F.2d 363, 370-71 (8th Cir. 1949) ("The inconsistency] to our minds weakened the presumption of correctness usually attributable to the verdict of a jury."); United States v. General Motors Corp., 121 F.2d 376, 411 (7th Cir), cerl. denied, 314 U.S. 618 (1941) ("We can not understand how the jury could have acquitted all of the individual defendants. As a matter of logic, reconciliation between the verdict of guilt and verdict of acquittal is impossible.") But see United States v. American Stevedores, Inc., 310 F.2d 47, 48 (2d Cir. 1962), cert. denied, 371 U.S. 969 (1963) (alternative ground) (acquittal of employees not inconsistent with conviction of entity where jury reasonably could have concluded that higher-level managers not brought to trial were actual culprits in fraud committed on behalf of corporation).

28. E.g., 33 U.S.C. $\$ 938$ (b) (1970) (where corporate employer has destroyed or concealed property with intent to avoid paying compensation under the Longshoremen's and Harbor Workers' Compensation Act, corporation's president, secretary, and treasurer are severally liable for any penalty of imprisonment as well as jointly liable with corporation for any fine).

29. E.g., 12 U.S.C. $\$ 378(a)$, (b) (1970) (officers, directors, employces, and agents liable for violating prohibition against securities dealers engaging in banking business); Clayton Act $\$ 10,15$ U.S.C. $\$ 20$ (1970) (directors, agents, managers, and officers liable for voting for, directing, or aiding or abetting contracts between common carriers with interlocking directorates); 21 U.S.C. $\$ 622$ (1970) (agents and employees liable for bribery of meat inspectors); 30 U.S.C. $\$ 819$ (c) (1970) (directors, officers, and agents liable for knowingly authorizing, ordering, or carrying out violation of mandatory mine safety standards).

30. United States v. Wise, 370 U.S. 405, 409 (1962) (construing Sherman Act, $\$ 1,15$ U.S.C. $\$$ I (1970)); United States v. Dotterweich, 320 U.S. 277, 284-85 (1943) (construing $\$ \$ 301(a), 303(a)$ of Federal Food, Drug, and Cosmetic Act, 21 U.S.C. $\$ \S 331(a), 333(a)$ (1970)). 
ployees. Of course, criminal liability attaches to the employee who personally performs the forbidden conduct-the worker who intentionally mislabels a drug shipment or the messenger who knowingly delivers corporate payments to a politician. ${ }^{31}$ But responsibility in this most literal sense may also be the least meaningful, for focusing sanctions exclusively on corporate underlings may vitiate a statute's deterrent effect. ${ }^{32}$ Active participation in a corporate offense may also take the form of directing the lawbreaking conduct of others; where there is evidence of authorization to commit the illegal act, courts have had little difficulty imposing penal sanctions on the superior corporate employees who gave that authorization. ${ }^{33}$ Frequently, however, there is no evidence of explicit direction to transgress the law, and the liability issue is whether a corporate employee who assented to, acquiesced in, or failed to halt illegal conduct by others is criminally responsible. In these situations of passive participation, courts usually have approved penal sanctions only when the applicable statute imposed an affirmative managerial duty and the employee charged was a corporate executive. ${ }^{34}$

31. In keeping with this principle, S. 1, 94th Cong., 1st Sess. $\$ 403$ (a) (1975), quated at note 8 supra, would impose employee liability for lawbreaking on behalf of the corporation "to the same extent" as if the employee engaged in or caused the violation on his own behalf.

32. Of course, corporate executives could also be liable under this literal notion of responsibility. See, e.g., United States v. American Radiator \& Standard Sanitary Corp., 433 F.2d 174, 180-81 (3d Cir. 1970), cert. denied, 401 U.S. 948 (1971) (executives of several corporations attended meetings to promote price-fixing conspiracy); United States $v$. Carter, 311 F.2d 934, $937-38$ (6th Cir.), cert. denied, 373 U.S. 915 (1963) (corporate president personally made unlawful payment to union official).

33. See, e.g., Imperial Meat Co. v. United States, 316 F.2d 435, 440 (10th Cir.), cert. denied, 375 U.S. 820 (1963) (plant supervisor liable for making false claims to government about quality of meat, based on testimony that he had signaled subordinates when to process substandard meat); United States v. Empire Packing Co., 174 F.2d 16, 19 (7th Cir.), cert. denied, 337 U.S. 959 (1949) (corporate president liable for violating price ceilings by instructing certain employees to obtain side payments from customers buying meat); Mininsohn v. United States, 101 F.2d 477, 478 (3d Cir. 1939) (corporate officers liable for defrauding government by telling truckdriver to seal underweight bags of cement for delivery to federal construction project).

34. See, e.g., United States v. Park, 421 U.S. 658, 670-73 (1975) (corporate president headquartered in Philadelphia liable for failure to prevent or correct unsanitary conditions in Baltimore warehouse); United States v. Andreadis, 366 F.2d 423, 430 (2d Cir. 1966), cert. denied, 385 U.S. 1001 (1967) (alternative ground) (corporate president liable for failure to insure accuracy of product endorsements by firm's advertising agency).

S. 1, 94th Cong., Ist Sess. $\$ 403$ (b) (1975), quoted at note 8 supra, seeks to codify this decisional law by providing that where a statute or regulation imposes an affirmative duty on an organization, an employee "having significant responsibility for the subject matter of the duty is criminally liable for an offense based upon an omission to perform the duty." Since the bill includes no definition of "responsibility," one can only speculate on the scope of the liability that would be imposed by this section.

Passive participation in a criminal offense may under certain circumstanccs sustain liability for conspiracy. Conspiracy law can reach corporate decisionmakers who assent to lawbreaking action but not those who acquiesce in or fail to halt such action, unless 
Despite the web of penal statutes surrounding corporate entities and employees, the capacity of the criminal law to control corporate crime has been widely discounted. ${ }^{35}$ The basic problem is that the law is not founded on an understanding of the decisionmaking process that the law must shape in order to deter corporate lawbreaking. This is not to say that legislators, prosecutors, and judges have no conception of how corporate lawbreaking takes place. A legislator drafting a regulatory statute, a prosecutor framing his theory of a case, a trial judge giving jury instructions, or an appellate judge reviewing the admission of evidence-all work with assumptions about how corporate crime occurs and how that occurrence can be deterred most effectively. But legal policy has not been based on a systematic analysis of corporate decisionmaking that sets out the factual patterns and deterrence strategies implied by the various assumptions. As a result, the assumptions of legal policymakers are usually unarticulated and untested, and the actions based on those assumptions are often misguided.

In this regard, models of corporate decisionmaking may prove to be useful conceptual tools. Each model represents a set of consistent assumptions about corporate decisionmaking that legal policymakers can employ to analyze instances or patterns of corporate lawbreaking. Each model associates certain facts with its assumptions, and thereby each can guide legal policymakers to evidence that validates or invalidates those assumptions. Lastly, in accordance with its distinctive characterization of corporate decisionmaking, each model implies that certain deterrence strategies are most likely to be effective. Thus, having systematically determined which characterization is warranted, legal policymakers can select the appropriate strategy to prevent corporate lawbreaking.

The definition of criminal responsibility that emerges from decisionmaking models is a functional one: responsibility lies with whichever corporate decisionmakers were capable of preventing the corporate offense that occurred. The models imply that the identity of these decisionmakers varies according to the character of the corporate decisionmaking process. By illuminating that process, the models can benefit legislators trying to fashion statutes to control corporate conduct as well as prosecutors and judges trying to formulate precise theories of liability from general legislative provisions. The result should

their passivity is in furtherance of an agreement to commit a criminal offense, an agreement to which they are parties. The substantive shortcomings and procedural inequities of present conspiracy law are discussed in Working PAPERs, supra note 3, at 386-400.

35. See, e.g., Davids, Penology and Corporate Crime, 58 J. Crim. L.C. \& P.S. 524 (1967); Comment, supra note 1, at 283-90, 294-97; sources cited note 2 supra. 
be legal policymaking that more effectively deters corporate crime. First, because the models would make the boundaries of criminal responsibility more intelligible to corporate decisionmakers, the latter should be encouraged to shape their actions in accordance with the law. Second, because the models would help legal policymakers discern how a corporate violation occurred and which decisionmakers might have prevented it, the law should represent a more credible threat to potential offenders. Finally, because the sanctions imposed in accordance with the models would be tailored to have maximal impact on the particular offender, convicted corporate lawbreakers should be more effectively induced to prevent subsequent violations. The remainder of this Note constitutes an initial effort to elaborate this argument and to demonstrate the value of decisionmaking models in achieving deterrence of corporate crime.

\section{The Models: Rational Actor, Organizational Process, and Bureaucratic Politics}

Each of the three decisionmaking models applied in this Note has been employed extensively, with slight variations in terminology and emphasis, by those who study organizations. ${ }^{36}$ Nevertheless, the application of these models to corporate criminal law warrants two important caveats. First, the models are not wholly realistic. They do not, and are not intended to, capture the variety and intricacy of corporate decisionmaking. Rather, each serves as a "conceptual lens" which magnifies, highlights, or reveals certain aspects of the decisionmaking process and blurs or neglects others. ${ }^{37}$ Second, the models are not exhaustive. Other models, as well as modifications and combinations of the three introduced here, could provide new insights. ${ }^{38}$ For the purpose of this Note, however, three models suffice: their different characterizations of corporate decisionmaking demonstrate the utility of models and yield diverse implications for the control of corporate crime.

The Rational Actor Model (Model I) is based on two propositions familiar to economists. ${ }^{39}$ The first proposition is that corporate action

36. The three models are drawn from a variety of works, particularly G. ALIIson, supra note 7, and other sources cited notes 39-45 \& 48-56 infra. The models take their names from $i d$. at 4 passim.

37. The metaphor is Professor Allison's. Id. at v.

38. See note 57 infra.

39. The tenets of Model I derive mainly from the neoclassical economic theory of the firm. See, e.g., H. Leibenstein, Economic Theory and Organizational Anilysis 3-40 (1960); J. MCGuiRe, TheORIES OF Business BeHAvior 46-72 (1964). For a statement of Model I that depends more on political science, sec G. Allison, supra note 7, at 10-38. 
should be treated as unitary-as if decisions were made by a singleminded actor, the corporate entity. Since the entity itself is the decisionmaker, the decisionmaking process is activated by corporate problems, framed by corporate alternatives, and guided by corporate values. Model $I$ is not blind to the existence of individuals beneath the corporate façade-even individuals who are occasionally irrational. ${ }^{40}$ Rather, the model regards the behavior of corporate employees as sufficiently concerted to justify synthesizing their numerous individual acts into a corporate decisionmaking process that can be characterized as unitary.

The second proposition underlying Model $\mathrm{I}$ is that corporate action should be treated as rational-as if the corporate entity chose from among all available options the course of action that would maximize its values. ${ }^{11}$ Typical corporate options include choice of personnel, products, and markets. Corporate values may include profit, the single value traditionally posited by neoclassical economic theory, as well as others that have been suggested by observers of corporate behavior. ${ }^{42}$

The Rational Actor Model's conception of unitary, rational decisionmaking differs sharply from the characterization of corporate action provided by the Organizational Process Model (Model II). Instead of the unitary actor postulated in Model I, Model II conceives of the corporation as a constellation of loosely allied decisionmaking units (e.g., a marketing group, a manufacturing division, a research and development staff), each with primary responsibility for a narrow range of problems. Though all units operate within general corporate

40. Sce C. Bariand, The Functions of the Executive 186 (1938).

41. Model $I$ does not insist that the corporate entity be omniscient; the costs and benefits of some options may have to be estimated. Thus, Model I can encompass decisionmaking under risk (when each alternative leads to known consequences or to a set of consequences with a known probability distribution) or decisionmaking undcr uncertainty (when at least one alternative leads to a set of consequences with an un. known probability distribution). See R. Luce \& H. Raiffa, GaMes aNd Decisions 13 (1957). Within the constraints imposed by imperfect knowledge, the corporation characterized by Model I would still act as a value maximizer.

42. Starbuck, Organizational Growth and Development, in HANDBook of ORGanizations 451, 454.64 (J. March ed. 1965), reviews the literature on organizational goals. Among those goals are a number which reflect commonly cited cosporate values: profit, prestigc, executive salaries, revenue, and stability. The cconomic theory supporting this diversity of corporate values is discussed in Alchian, The Basis of Some Recent Advances in the Theory of Management of the Firm, $14 \mathrm{~J}$. InDus. Econ. 30 (1965). Any theory that postulates value maximization (regardless of the values) is consistent with Model $\mathrm{I}$.

An alternative theory of corporate behavior is that the firm "satisfices" rather than maximizes values: instead of seeking to make choices from among all possible options, the firm focuses its attention on a narrow range of alternatives to which it is institutionally predisposcd. H. Simon, Models of MAN: Social aNd Rational 204-05, 241-56 (1957). Such a satisficing theory is generally considered inconsistent with Model I. See, e.g., J. McGuire, supra note 39, at 32-34. But see Alchian, supra at 39-40 (arguing that satisficing is constraint on maximizing rather than contradiction of it). 
guidelines, the complexity and breadth of corporate operations allow each unit to exercise some autonomy in setting priorities, defining problems, processing information, and taking action. At the same time, important operations transcend the jurisdiction of any one unit, so that executive intervention is necessary to coordinate the activity of the decentralized decisionmakers.

According to Model II, however, an executive works under certain constraints, for the actions of the corporation's decisionmaking units are not rational. Rather, action is determined largely by preexisting organizational routines, and decisionmaking is structured by the problems identified, information gathered, and actions initiated according to these routines. ${ }^{43}$

When a decisionmaking unit perceives a familiar problem, it refers to its standard operating procedures (SOPs) established to cope with the type of problem involved. SOPs are generated in various ways. Some are introduced through oral or written directives which articulate the corporate practices to be followed under stated circumstances by employees filling specified positions in the organization. Others emerge from customary ways of accomplishing certain everyday tasks, with routinization resulting from force of habit rather than specific instruction. According to Model II, most corporate actions (e.g., replying to consumer complaints, maintaining quality control, disposing of waste material) consist simply of subcorporate units following these regularized procedures. ${ }^{44}$

The viability of corporate action based on established procedures depends on the ability of subcorporate units to narrow the range of unexpected problems. Units seek to avoid uncertainty by negotiating with other units and competitors. ${ }^{45}$ Negotiation with other units may

43. Two key elements of the Model II corporation-specialization and routinizationcan be found in Max Weber's "ideal type" bureaucracy. From Max Wener: Essays in Sociology 214-16, 228-30 (1958 ed.) [hereinafter cited as Weber Essays]; M. WebrR, TuE Throry of Social AND Economic Organization 337-41 (1947) [hereinafter cited as Economic OrG.inizition]. The shortcomings of bureaucracy have been analyzed in G. Arlison, supra note 7, at 67-100; M. Crozier, The Bureaucratic Phenomenon 175-208 (1964); R. Merton, Social Theory and Social Structure 197-202 (rev. cd. 1957). The seminal work in the development of Model II is H. SimoN, supra note 42, at 241-73. For discussion and claboration of Professor Simon's work, sce R. CYERT \& J. M.ARCH, A Behavioral Theory of the FIRM 26-127 (1963); Feldman \& Kanter, Organizational Decision Making, in Handbook of ORganizations, supra note 42, at 614, 618-28.

44. The SOP concept introduced here collapses a hierarchy of concepts-repertoire, program, standard operating procedure-used in G. AlLisox, supra note 7, at 81-85. Professor Leibenstein similarly characterizes the decisionmaking process in terms of "stand. ing rules of choice" (comparable to Professor Allison's SOPs) and "standing policies," "series of statements which someone faced with a certain area of decision-making situations can translate into rules of choice or the choices themselves." H. Leibexstein, supra note 39 , at 254 .

45. See R. Cyert \& J. MARCh, supra note 43, at 118-20. 
reduce uncertainty about such matters as primary responsibility for particular corporate tasks or allocation of prospective budget increases. Negotiation with competitors may concern development of product lines, entry into new markets, or lobbying efforts for legislative or executive action. ${ }^{40}$

Despite negotiation, some degree of uncertainty is inescapable; on occasion, unfamiliar or unpredictable problems do arise. When a unit confronts such a problem, it initiates "search"-a sequential canvass for applicable SOPs, beginning with those designed for apparently analogous circumstances. Thus, according to Model II, a corporate action is not tailored to the situation at hand but rather reflects the most appropriate of the available SOPs. The action may be ill-suited if the situation does not conform to a scenario anticipated by the subcorporate unit. ${ }^{47}$

The Bureaucratic Politics Model (Model III) diverges significantly from each of the other models. Corporate action under Model III is neither rational calculus nor routinized procedure but, rather, political resultant. It is the outcome of a bargaining game involving a hierarchy of players and a maze of formal and informal channels through which decisions are shaped and implemented. ${ }^{48}$ Each decision can be conceived as a single game, ${ }^{49}$ with the identity of the players (e.g., plant manager, marketing specialist, chief lobbyist) dependent both on the issues involved and on the organizational structure.

46. The organizational effort to cope with uncertainty through a negotiated environment can be limited by the law. Thus, Professors Cyert and March criticize current antitrust policy on the ground that it tries to enforce competition by maintaining uncertainty (i.e., blocking the exchange of information among competitors). They recommend that the government help develop better forecasting techniques and thereby cncourage firms to avoid uncertainty without restricting competition. Id. at 295-97.

47. For example, a corporate laboratory charged with testing the safety for human consumption of food products that the firm is planning to market may routincly test the products on aclult mice. If the same routine is followed when the firm introduces a line of baby foods, the failure to test the products on young mice may yield unreliable results. See J. Turner, The Chemicai. Feast 88-91 (1970).

48. Max Weber's emphasis on hierarchy and roles anticipated the formulation of Model III. See Weber Essays, supra note 43, at 198-204; Economic Organization, supra note 43 , at $333-36$. Since then, Model III has undergone both theoretical refinement and empirical testing. Particularly important contributions to the literature are G. Allison, supra note 7, at 144-84; M. Dalton, Men Who Man.ige: Fusions of Feeling and Theory in Administration 18-109 (1959); A. Downs, Inside Bureaucricy 79-111 (1967); H. LEIBENSTEIN, stepra note 39, at 119-54, 172-85. For organizational case studies with a Model III orientation, see M. CRoziER, supra note 43, at $112-42$ (French industrial monopoly); A. Pettigrew, The Politics of Organizitional Decision-making (1973) (British retail firm).

49. Model III, borrowing from game theory, uses the term "game" to refer to the structured interaction of individuals cmploying strategies in accordance with certain rules. The classic definition of such a "game" is set forth in J. voN NEUMANN \& O. Morgenstirn, Theory of Gamis and Ecónomic Bfhavior 48-60 (3d ed. 1953). For a nontechnical application of game theory to the business world, sec J. McDonald, ThE GaMe of Business (1975). 
Since separate individuals with different intentions contribute to the political outcome, actual corporate action may not be the preferred course of any particular player or team. It may be an amalgam of independent decisions, a compromise among the views of several teams, or the relatively unalloyed preference of a certain subset of players. Moreover, even if the decision is unanimously supported, the support may stem from dissimilar interpretations of the proposed action. Indeed, the pace and pressures of bureaucratic bargaining make misunderstandings among players common-and often crucial to reaching a consensus. ${ }^{50}$ Finally, what is planned may not correspond to what is implemented. The need for vagueness in order to build consensus in the formulation stage may be exploited by subsequent maneuvers in the implementation stage.

During a particular game, a given player's participation may vary considerably. He may be quite active in early stages (e.g., when alternative solutions are being identified) and inactive thereafter; or he may not have an opportunity to start bargaining until the basic course of action has already been set. Individuals who are officially nonparticipants may in fact be influential on certain matters; on the other hand, those who, according to the organization charts, have authority in a specific area may be circumvented by other players.

Organization charts are not irrelevant under Model III, however. Becaúse of his position, each player holds particular bargaining chips, feels committed to specific projects, remains sensitive to parochial issues, and strives to attain certain corporate and subcorporate objectives. Each player also carries his own "baggage" (e.g., personal goals, ${ }^{51}$ stature with and obligations to various extracorporate groups or individuals, ${ }^{52}$ and skill in bureaucratic infighting ${ }^{53}$ ).

Bargaining among players is structured by laws, corporate charters, corporate policies and practices, market forces-in short, by the rules according to which all corporate games are played. These rules collectively establish the positions of the players, the paths of access to these positions, the inherent power of each position, the routes particular

50. G. Allison, supra note 7, at 178; see R. Mack, Planning on Uncertainty: Decision Making in Business and Government Administrition 130 (1971) ("Uncertainty can make coalitions possible which clarity would disrupt.")

51. The personal goals most commonly cited in the literature on managers are high salary, security, status, power, prestige, service to society, and professional excellence. $O$. Williamson, The Economics of Discretionary Behavior: Managerial Objectives in $A$ TheORY OF THE FirM 28-32 (1967).

52. The influence on corporate decisionmakers of financiers, suppliers, customers, competitors, labor, government, and other groups is discussed in $R$. Gordon, Business LeADERShip in THE LARGe CoRPORATION 147-55, 189-267 (2d ed. 1961).

53. See W. Moore, The Conducr of the Corporation 113-16, 124-29 (1962). 
decisions must follow from player to player, and the boundaries of acceptable conduct. Thus, although Model III, like Model II, denies the validity of Model I's propositions of unitary and rational decisionmaking, it does so in a different way. First, it emphasizes the multiplicity and parochialism of intracorporate groups and individuals. Second, it stresses the conflict and compromise that underlie corporate action.

This second facet of Model III contradicts Model I rationality in two respects. The result of the Model III decisionmaking process is only by coincidence, if at all, the course of action that maximizes the values of the entity as a whole. ${ }^{54}$ Furthermore, the Model III process itself lacks the qualities of purposefulness ${ }^{55}$ and consistency that are basic to Model I decisionmaking. The irrationality of Model III decisionmaking thus is due not to any mental quirks of the decisionmakers but rather to the organizational system in which they interact. ${ }^{56}$

\section{Implications for Legal Policy}

Although one of the implications of decisionmaking models is that no single conception of corporate decisionmaking is always adequate, this part of the Note considers each model separately in order to clarify the distinctive insights that each offers. ${ }^{57}$ The discussion focuses on the utility of the models for legislators, prosecutors, and judges.

54. It may be argued that the Model IIt decisionmaking process must invariably result in profit maximization or else the firm would not survive economically. It is true that distortions in a firm's performance due to managerial discretion theoretically are checked by competition in both product and capital markets. But if the firm exercises some degree of market power or stockholders have insufficient knowledge or interest to displace management, such distortions may continue without threatening the survival of the firm. O. Willimison, Markets and Hierarchies: Analysis and Antitrust ImplicaJTaNs 135 (I975).

55. Two senses of "purposefulness" can be distinguished. First, purposefulness may refer to the common orientation of members of an organization. Second, purposefulness may refer to the personal goals and ambitions which motivate each individual. $V$. Thompson, Modern Organization 81 (1961). Model I recognizes purposefulness only in the first sense; Model III emphasizes the second.

56. As Professor Schelling has written, irrationality may result from

a disorderly and inconsistent value system, faulty calculation, an inability to receive messages or to communicate efficiently; it can imply random or haphazard influences in the reaching of decisions or the transmission of them, or in the receipt or conveyance of information; and it sometimes merely reflects the collective nature of a decision among individuals who do not have identical value systems and whose organizational arrangement and communication systems do not cause them to act like a single entity.

T. Schelling, The Stritegy of Conflict 16 (1960).

57. Additional insights into corporate decisionmaking could be gained through the application of other models and the modification and combination of the three discussed in this Note. An example of another model is the "cognitive paradigm" proposed in J. Steinbruner, The Cybernetic Theory of Decision: New Dimenstons of Political ANalysis 112, 123-24 (1974). Professor Steinbruner, drawing on both cybernetic and 


\section{A. The Rational Actor Model}

According to the Rational Actor Model, corporate lawbreaking results from the purposeful, consistent acts of the corporate entity. Model I suggests to legal policymakers that the key to controlling corporate crime is to focus on the rational calculus that underlies corporate violations.

Legislators taking a Model I approach would try to influence corporate entity actions by manipulating corporate values and corporate options. Manipulation of corporate values (e.g., the primacy of profits) may be beyond the capacity of law, for the values are likely to be imbedded firmly in the cultural environment of the corporation as well as in the psyche of corporate management.58 In contrast, manipulation of corporate options seems well within the power of the criminal law. Legislators can criminalize, and therefore penalize, the exercise of certain options. Consequences of illegal options can be made more costly by increasing the penalties associated with them or by increasing the probability that the penalties authorized for an illegal option will actually be imposed. Another means of raising costs is to impose criminal penalties on corporations that choose socially disfavored options unless they engage in resource-consuming activities (e.g., filing reports, obtaining clearances). ${ }^{50}$ In sum, the aim of legislative

cognitive theory, suggests that organizational decisionmaking is shaped by three mental responses to uncertainty: "grooved thinking" (classifying every problem according to a few critical variables and then applying a decision rule for that class); "uncommitted thinking" (oscillating among competing belief patterns about feasible and desirable policies as conflicting information and advice are brought to bear); and "theoretical thinking" (ignoring or discounting evidence inconsistent with strong, generalized commitments to certain values and views). Id. at 125-36.

An example of model modification is relaxation of Model I's unitary actor assumption, yielding a model in which rationally self-interested managers operate their firm so as to maximize staff, "emoluments, and "discretionary profit" subject to a minimum profit constraint. "Discretionary profit" is revenue available for discretionary use by the managers after taxes and expenditures essential for maintaining the viability of the firm.) See O. Willamson, supra note 51, at 38-60.

As for model combination, what might be described as an embryonic hybrid of Models II and III is presented in Cleland, $A$ Short Essay on a Managerial Theory of the Firm, in Linear Programming and the Theory of the Firm 202 (K. Boulding \& $W$. Spivey eds. 1960). Professor Cleland focuses on the "manager-executive" as a decisionmaker who promulgates standardized company policies and procedures in order to compensate for deficiencies in information and to restrict the tactical maneuvering of subordinates.

58. On the impact of cultural values on business behavior, see M. WEBER, ThE Protestant Ethic and the Spirit of Capitalism (1958); W. Whyte, The Organizition Man 3-59, 141-67 (1956). The role of values in the mental processes of decisionmakers is discussed in J. Steinbruner, supra note 57, at 103-36. See also D. Riesmin, The Lonely Crowd: A Study of the Changing American Character 115-47 (1950). For a view that law is capable of shaping corporate values, see Rostow, To Whom and For What Ends is Corporate Management Responsible?, in The Corporition IN MODERN SOciety 46, 70.71 (E. Mason ed. 1959).

59. See, e.g., 12 U.S.C. $\$ 1730 a(e)(1)(B)$ (1970) (requiring companies seeking to acquire financial institutions insured by Federal Savings and Loan Insurance Corporation to 
policy under a Model I approach would be to effect the substitution of desirable courses of action for undesirable ones by influencing the corporate calculus.

Model I also provides some guidance as to the types of sanctions which legislators should authorize in order to weight the scales of corporate choice against undesirable actions. Model I argues for imposing sanctions on the corporate entity rather than on employees, for the entity is the decisionmaking unit. The specific sanctions should depend on the specific values that influence the corporation's conduct. ${ }^{60}$ Conceivably, legislators confident that all corporations maximize the same value or values could include in every pertinent criminal statute a particular corporate sanction tailored to that universal behavioral norm. For example, if profit maximization were considered the norm, a fine determined by the entity's profitability during the period of the offense could be imposed; ${ }^{01}$ or the fine could be set so as to cancel out any profits reaped from the illegal action, ${ }^{62}$ perhaps with a suitable multiplier to adjust for the probability of being convicted for the offense. ${ }^{63}$ Similar sanctions could be devised for other corporate values, such as sales volume. ${ }^{64}$

Alternatively, entity sanctions could concentrate on intermediate values whose maximization lays the foundation for the attainment of profit or sales targets. For example, the convicted corporation could be prohibited from bidding on government contracts, obtaining government franchises, or otherwise benefiting from government

obtain prior written approval of FSLIC); 30 U.S.C. $\$ 842$ (c) (1970) (requiring mine operators unable to comply with Department of Interior dust concentration standards to file detailed report of mine conditions with application for noncompliance permit); 49 U.S.C. $\$ 5 \mathrm{~b}(2)$, (3) (1970) (requiring parties to rate agreement among common carriers to obtain prior approval from and submit reports to ICC). Such means of raising costs are useful regardless of a corporation's values, because these activity costs constrain the maximization of all values.

60. For Model $I$, as for Models II and III, identification of the values of a particular decisionmaker would be a fact-finding task for a congressional inquiry, a prosecutorial investigation, or a trial interrogation.

61. See Breit \& Elzinga, Antitrust Penalties and Attitudes Toward Risk: An Economic Analysis, 86 HARv. L. REv. 693, 711 (1973) (proposing mandatory fine of $25 \%$ of firm's pretax profits "for every year of anticompetitive activity").

62. Professor Dershowitz has recommended attachment of illegal profits, which would have the same effect as a profit-negating fine. Comment, supra note 1, at 298-300.

63. R. Posner, Antrreust 110-12 (1974). This reflects the Model I conception of decisionmaking under risk described in note 41 supra. Cf. Comment, supra note 1, at 288.90 (contending that infrequency of treble damage recoveries makes that sanction an ineffective deterrent to potential antitrust offenders).

64. Sce M. Green, The Closed Enterprise System 175 (1972) (proposing corporate fines calculated as percentage of sales receipts for period covered by indictment). But see Breit \& Elzinga, supra note 61, at 710-11 (arguing that penalties based on sales would have widely varied impact depending on profit-sales ratios of firms). 
largesse. ${ }^{65}$ Likewise, to the extent that public goodwill is an intermediate corporate value, publicizing corporate convictions could be effective. ${ }^{66}$

Any one of these entity sanctions might be authorized by legislators who are confident that the chosen sanction would be optimally effective in controlling the conduct of all corporations. ${ }^{67}$ However, if legislators are uncertain as to which corporate values are dominant or believe that they vary among corporations, Model I suggests that statutes provide for a range of entity sanctions from which judges could choose in accordance with their analysis of the particular corporate offender.

From a Model I perspective, then, current federal statutory provisions for corporate penalties are deficient because they generally impose fines whose relation to corporate profits, sales, or other values is unclear. The severity of the sanction should continue to depend on the gravity of the offense, but the form of the sanction should be varied to strike most effectively at the values of the offending corporation.

Although Model I's major implication is that the locus of criminal liability should be the corporation, the model does not necessarily exclude the possibility of imposing sanctions on individual employees. However, since Model I conceives of the entity as the decisionmaker, it supports sanctions against employees only as a means of penalizing the entity. For example, if an experienced manager were imprisoned,

65. See J. Flynn, Criminal Sanctions Under State and Federal Antitrust Laus, 45 TEx. L. REv. 1301, 1332-33 (1967). But see Comment, supra note 1, at 289 n.35 (sug. gesting that this sanction is not likely to be imposed on corporations that dominate industries essential to functioning of government).

The recent implication of some of the nation's largest corporations in international commercial bribery has provoked threats of this form of penalty. President Ford reportedly spoke of disqualifying corporate offenders from bidding on federal contracts. N.Y. Times, Feb. 11, 1976, at 1, col. 8. Also, a Congressman reportedly proposed that corporations convicted of bribery lose government insurance against expropriation. Wall St. J., Feb. 13, 1976, at l, col. 5.

66. See Fisse, The Use of Publicity as a Criminal Sanction against Business Corporations, 8 Melb. U.L. Rev. 107 (1971); Working PAPERs, stupra note 3, at 191-92. All four congressional bills, described at note 3 supra, contain a section that provides for publicity as an organizational penalty (S. 1, $\$ 2004$; H.R. 10850, $\$ 2004$; H.R. 3907, \$ 2004; H.R. 333, § 3007).

67. Legislators might also authorize corporate probation as an alternative to any entity sanction. Judges could then suspend the monetary sentence of a convicted corporation and instead impose probationary conditions on the corporation. Such conditions could be more coercive than the fine normally imposed, because their violation could result in not only the imposition of the suspended sentence but also contempt citations against corporate officials and additional adverse publicity. Indeed, even without new legislation the low level of the fines authorized for most entity convictions may makc corporate probation more common. Cf. United States v. Atlantic Richfield Co., 465 F.2d 58 (7th Cir. 1972), noted in 3 U. BAxT. L. REv. 294 (1974), (holding Federal Probation Act, 18 U.S.C. $\$ 3651$ (1970 \& Supp. IV 1974), applicable to corporations). 
corporate profitability might suffer; $;^{68}$ if the conviction of corporate officials became known, the entity's public image might be tarnished. ${ }^{60}$ Nevertheless, legislators would have to circumscribe carefully such individual criminal liability to remain within the bounds of due process and to avoid gross personal injustices. ${ }^{70}$

Model I offers guidance not only to legislators but also to prosecutors. The implications of the model are useful to a prosecutor in collecting evidence pertinent to ascertaining how a criminal offense occurred as well as in integrating the evidence collected into a meaningful whole. For instance, in an investigation of suspected unlawful water pollution by a particular corporation, Model I would pose such questions as: What were the corporation's dominant values-sales of a new product line, retained earnings, reputation as a law-abiding corporate citizen, ranking of its executives' salaries within the industry? What priorities for corporate resource allocation flowed from these values-was pollution control a matter of importance in light of the corporation's primary objectives? What corporate costs and benefits would have accrued from each environmental policy option-what were the financial, social, legal, and other consequences of the pollution control choices available to the corporation, and how, given its values and priorities, would these consequences have been weighed?

These Model I questions serve a dual purpose for the prosecutor. First, they focus the prosecutor's investigation on the suspected corporate polluter's values, priorities, and calculations, and thereby draw attention to facts that might otherwise be ignored or considered irrelevant. ${ }^{71}$ Second, they help the prosecutor to compare the factual

68: Cf. Whiting, Criminal Antitrust Liability of Corporate Representatives, $51 \mathrm{Kx}$. L.J. 431, 446 n.40 (1963) (quoting corporate executive to effect that drain on time of defendant managers who must help prepare their case for trial may itself be costly penalty for corporate entity).

69. But see Comment, sitpra note 1, at $289 \mathrm{n.35}$ (expressing doubt that moral opprobrium which attaches to convicted executive also tarnishes his corporate employer).

70. Model I's individual liability is actually entity liability transferred to corporate employees who may have played no role in the offense. This peculiar form of vicarious liability has never been proposed, though other forms of vicarious liability have been suggested as means to control corporate crime. See H. PePINskY, supra note 2, at 139-4I (recommending collective liability of all employees for corporate offenses); WoRkING PAPERs, supra note 3 , at 185.88 (discussing vicarious liability alternatives applicable to corporate managers).

71. For example, Mrodel I suggests that a prosecutor sifting evidence in a water pollution case should consider whether violation of the statute was efficient from the corporation's standpoint. If the cost of complying with the statute exceeded the fine for violation, discounted by the risk of conviction, then a prima facie Model I case could be made against a profit-maximizing firm, because it would be rational for such a firm to violate the statute. If profit were not the firm's sole valuc, the corporate calculus would differ, but the prosecutorial task would remain the same: to determine whether the statutory violation could be conceived as the decision of a unitary, rational corporate entity. 
patterns he observes with those patterns corresponding to a Model I conception and thus to determine the advisability of taking a Model I approach to the case.

The prosecutor's use of Model I would in turn influence the conduct of the trial judge. In instructing the jury on grounds of liability, in ruling on admission of evidence, in imposing penalties on the defendant upon conviction, and in a variety of other situations, the trial judge's decisions would depend on the prosecutor's perceptions of the offense and the offender as well as on the judge's independent evaluation of the case. If the offense were allegedly the result of a careful weighing of corporate costs and benefits, then the admission of evidence concerning corporate values and priorities would be crucial for the jury's deliberation; if the offense were allegedly the result of a standard operating procedure gone awry, the same evidence might be properly challenged as irrelevant. Likewise, imposing a corporate fine as a function of profitability might be an effective deterrent to an entity that rationally seeks to maximize profits; it would be less effective if the entity were simply a façade for competing managerial factions interested chiefly in self-advancement.

An appellate judge, in reviewing these decisions of the trial judge, necessarily would evaluate the latter's analysis of the offense and the offender; thus, decisionmaking models would be useful at the appellate level as well. For example, if the corporate defendant appealed a ruling that a corporation is considered to have acquired the collective knowledge of all its employees, ${ }^{72}$ the appellate court could frame its decision in terms of the applicability of Model I to the case. In this way, too, the scope of appellate opinions could be more precisely delineated by articulating the factual patterns to which the holding applies. A holding appropriate to a Model I situation would not, then, be misapplied to circumstances in which other models are more germane.

Judges, prosecutors, and legislators seeking to determine the applicability of Model I to a given instance or pattern of corporate lawbreaking should consider a number of variables which shape the decisionmaking process. The structure of the market in which the corporation operates may affect its decisionmaking. Economic theorists

72. An exemplary statement of this Model I view was made in a recent district court opinion holding a corporation liable for violation of the Interstate Commerce Act:

[A] corporation cannot plead innocence by asserting that the information obtained by several employees was not acquired by any one individual employee who then would have comprehended its full import. Rather, the corporation is considered to have acquired the collective knowledge of its employees and is held responsible for their failure to act accordingly.

United States v. T.I.M.E.-D.C., Inc., 381 F. Supp. 730, 738 (W.D. Va. 1974). 
often contend that value-maximizing (more specifically, profit-maximizing) firms are likely to predominate in highly competitive markets. $^{73}$ Competition threatens inefficient firms with economic failure and thus forces value-maximizing discipline on corporations.

Regardless of market structure, organizational structure is a crucial variable. The fewer persons and the fewer hierarchical levels involved in the particular corporate decision, the more likely is Model I to provide useful insights for legal policymakers. Among small firms, these qualities are common to corporations owned and operated by the same people. Though such corporations are not necessarily profit-maximizing, ${ }^{74}$ their actions are generally the result of a weighing of corporate costs and benefits as perceived by a like-minded (perhaps familial) group-a decisionmaking process closely approximating Model I. ${ }^{75}$ Model $I$ is less relevant to large corporations than are Models II and III. Its relevance is probably limited to large firms that minimize involvement of people and hierarchical levels through quasi-autonomous operating divisions organized mainly along geographical, brand, or product lines. The corporate headquarters then concentrates on strategic decisions, including allocation of resources among the operating divisions, and leaves operating decisions to the divisions. ${ }^{76}$

Significantly, the organizational structures most conducive to Model I analysis are also those that pose the least difficult questions of criminal responsibility. More difficult questions are posed by the involvement of hierarchies and large numbers of people. Unfortunately, uncritical acceptance of the Model I conception of corporate

73. See, e.g., O. Williamson, stpra note 51 , at $170-72$ (suggesting that model comparable to Model $I$ is most applicable to competitive markets and one combining Models I and III is most applicable to monopolistic markets).

74. J. Decks, The SMall Firm Owner-Manager: Entrepreneurial Behayior and Managenevt Practice 185-208 (1976).

75. The extreme of this corporate form is the firm that is the alter ego of one percon, who assumes all managerial roles and personally supervises the work of the other employces. When such a firm violates the law, it would scem particularly sensible and effective to prosecute the individual decisionmaker on Model I grounds, because corporate policy would have been made by a unitary actor and because the entity would be harmed greatly if deprived of the expertise and experience of its single manager. $C f$. United States v. H.B. Gregory Co., 502 F.2d 700, 703-04 (7th Cir. 1974), cert. denied, 422 U.S. 1007 (I975) (both warehouse company and individual who was company's president, treasurer, and sanitation program director and who personally directed storage of goods, held liable for roclent infestation of warchouse); United States v. Empire Packing Co., 174 F.2d 16, 19.20 (7th Cir.), cert. denied, 337 U.S. 959 (1949) (both meat packing company and individual who was president of company, who owned all of its preferred and half of its common stock, who was in complete charge of plant operations, and who personally directed employees processing and selling meat, held liable for false grading of meat and for receipt of side payments violating price ceilings).

76. See O. Withismsos, supra note 54, at 136-38, 150 (contending that this corporate form, which Professor Williamson terms "multidivision form" or "M-form," favors goal pursuit and least-cost behavior associated with profit-maximization model). 
decisionmaking is evident among legal policymakers. ${ }^{7 \pi}$ To employ a Model I approach under circumstances suggesting that unitary, rational decisionmaking did not predominate is to sacrifice effective policy for the sake of facile conclusions. Failure to consider conceptions that help penetrate the corporate façade may cripple efforts to deter corporate crime. $^{78}$

\section{B. The Organizational Process Model}

The Organizational Process Model dissents from the Model I view that corporate actions can be interpreted as the results of unitary, rational decisionmaking by the entity as a whole. Model II's focus on subcorporate units discourages the reliance on entity liability endorsed by Model I. But this does not automatically compel advocacy of employee liability. Indeed, Model II suggests that employees have limited capacity to control the decisionmaking process within subcorporate units. Invariably there are disparities between the decisions individuals themselves would make-or do make-and the corporate action that emerges from a system of fragmented power and routinized procedures. Thus, one could contend that Model II argues against placing criminal responsibility on managerial or other employees by attributing to the corporate decisionmaking process qualities which would frustrate even able, law-abiding managers. ${ }^{79}$ This interpretation, however, distorts the implications of Model II. For the model's appreciation of the difficulties confronting management does not support immunization of corporate decisionmakers from individual liability. Rather, it underscores the importance of placing liability for corporate lawbreaking

77. For example, the existence of more than one model of corporate decisionmaking is not recognized in Economic Report of the President 149 (1975):

In weighing the costs and benefits of engaging in illegal activities, potential [antitrust] violators take into account the punishment if they are caught as well as the probability of successful prosecution. Increasing the penalty or the probability of apprehension, or both of these, raises the expected cost of illegal activity and should reduce its extent.

This statement reflects solely a Model I conception of potential violators, in that it posits rational, unitary decisionmaking under risk. See note 41 supra.

78. One of the themes of Thurman Arnold's critique of the American legal and economic system was that the effectiveness of corporate criminal statutes (specifically, the antitrust laws) had been vitiated by the perception of corporations as individuals. $T$. ARnold, The Folklore of Capitalisa 185-229 (1937).

79. This Model II argument against managerial liability is applicable a fortiori to lower-level employees. As Working PApers, supra note 3, at 198, notes with respect to liability under the Federal Food, Drug, and Cosmetic Act:

It seems clear that, as a practical matter, the assembly line worker following a set procedure for labeling who puts labels on jars as they come down the conveyer belt is not in a position to influence the method pursuant to which the process of labeling is conducted. Consequently, although he may be said technically to have been the "actor" who committed the crime of "misbranding," the coercive effect of criminal sanctions directed to him is probably nil. 
clearly and specifically on those in a position to promulgate and oversee the SOPs of subcorporate units.

Model II implies that corporate violations occur because existing SOPs mandate or allow illegal actions or because no SOPs exist to prevent illegal actions. Therefore, individuals with knowledge of the illegality or inadequacy of SOPs and with authority to correct them can most effectively ensure that corporate lawbreaking does not take place. Depending on the structure of the particular corporation, liability imposed on knowledgeable and authoritative employees could touch several managerial echelons-from top management of the organization through divisional executives to perhaps subdivisional supervisors. To prevent evasion of accountability by lower-level managers denying authority to modify unlawful SOPs and by higher-level managers professing ignorance of violations of SOPs, liability might also attach to those with either knowledge or authority.

Legislation embodying Model II liability principles would impose on individual corporate decisionmakers an affirmative duty to correct or attempt to correct SOPs they know to be flawed and to ferret out flawed SOPs they have the authority to correct. To encourage the fulfillment of this affirmative duty, statutes might require that corporations file reports about certain activities, thereby forcing a monitoring function on those officials responsible for preparing the reports. ${ }^{\mathrm{s}}$ Similarly, if regulatory agencies made an explicit practice of notifying particular corporate employees of first violations, they would facilitate successful prosecution of those employees for subsequent SOP offenses. ${ }^{\text {s1 }}$

80. One variant of this method of controlling corporate crime has been instituted by the Environmental Protection Agency. The National Pollutant Discharge Elimination System (NPDES) Regulations, 40 C.F.R. $\$ 125.12(f)$ (1975), require that under the Federal Water Pollution Control Act Amendments of 1972, 33 U.S.C. $\$ 1342$ (Supp. IV 1974), a corporation's application to the Environmental Protection Agency for a permit to clischarge a pollutant must be signed by "a principal executive officer of at least the level of vice president, or his duly authorized representative." See Glenn, The Crime of "Pollution": The Role of Federal Water Pollution Criminal Sanctions, 11 Am. Crim. L. REv. 835, 859-73 (1973).

For misrepresentations on NPDES applications a "responsible corporate officer" may be punished by a fine of up to $\$ 10,000$, imprisonment for up to six months, or both. 33 U.S.C. $\$ 1319(c)(2)$, (3) (Supp. IV 1974). A technical superintendent of an Allied Chemical Corporation Kepone plant recently pleaded guilty to violating this provision. See Wall St. J., Aug. 18, 1976, at 8, col. 3, and Criminal Information, United States v. Smith, Crim. No. 76-0129-R (E.D. Va., filed Aug. 17, 1976), superseding Indictment, Count 941, United States v. Allied Chemical Corp., Crim. No. 76-0129-R (E.D. Va., filed May 7, 1976) (both on file with Yale Law Journal).

Note that legally-imposed corporate duties, such as filing reports, are viewed by Model II as means of locating individual responsibility for monitoring SOPs, whereas they are perceived by Model I as means of consuming corporate resources and thereby raising the cost of certain entity options. See p. 1106 supra.

81. Such a practice has been followed by the Army Corps of Engineers with respect to corporate polluters in New York. Comment, supra note 2, at 80 . 
Prior government notice should not, however, be a requisite of criminal liability ${ }^{82}$ If it were, managers might have little incentive to monitor SOPs prior to a governmental investigation. In contrast, the objective of Model II legislation would be to prescribe legal responsibility for the lawfulness of SOPs, so that corporate managers who issue SOPs do not insulate themselves from information about implementation $^{83}$ and so that they do not acquiesce in unlawful or malfunctioning SOPs issued by others. ${ }^{54}$ To carry out the managerial responsibility imposed by such legislation, corporate managers could incorporate a feedback procedure in every SOP or could implement a wide-ranging SOP designed to elicit information about the workings of all SOPs in the particular corporate unit. ${ }^{85}$

Though Model II strongly suggests that corporate criminal laws place liability on certain managerial employees, its implications for criminal sanctions are less clear. The indeterminacy of Model II with respect to the choice of sanctions stems from two characteristics of the model. First, Model II fails to illuminate the motivation of the deci-

82. Cf. 21 U.S.C. $\$ 676(b)(1970)$ (authorizing Secretary of Agriculture to refrain from reporting for prosecution minor violations of meat inspection laws "whenever he believes that the public interest will be adequately served by a suitable written notice of warning").

83. One of the most notorious examples of an inadequate mechanism for notifying top management of a malfunctioning SOP is General Electric's Directive Policy 20.5, which was in effect during the 1950s. The directive forbade employees from entering into " 'any understanding, agreement, plan or scheme" " with any competitor concerning prices or terms of sale. J. Herling, The Great Price Conspiracy 53-54 (1962). Each employee received a copy of the directive and was instructed to sign it and return it to the legal counsel of his division. When General Electric and several of its executives were indicted in 1960 for conspiring with competing manufacturers of heavy electrical equipment to fix prices and bids, the company's highest officers insisted that they had never known that the directive was being disobeyed. Id. at 23-38, 198-99. Had the antitrust laws been drafted or interpreted according to Model II principles of liability, these officers might have been held criminally responsible for their failure to ensure enforcement of the directive they had promulgated, where that failure resulted in criminal offenses.

84. Acquiescence in illegal SOPs is particularly common when an employee new to his managerial position finds the SOP already in place. Thus, successive comptrollers of Gulf Oil Corporation evidently accepted without inquiry the usual procedure for authorizing the transfer of funds requested by Gulf's chicf lobbyist, a procedure that was integral to a complex scheme for laundering corporate political contributions. See Report of the Special Review Committee of the Board of Directors of Gulf Oil Corporation 37-52, SEC v. Gulf Oil Corp., Civ. No. 75-0324 (D.D.C., filed Dec. 30, 1975) (report issued pursuant to injunctive order) (on file with Yale Law Journal) [hereinafter cited as Gulf Committee Report].

The Special Review Committee that made an exhaustive investigation of the laundering scheme concluded with respect to the Gulf comptroller from 1968 to 1974 :

The Committee believes that [he] found himself in a very difficult position having to balance his duties as Comptroller with what he, no doubt, felt was a well established course of action approved by those who at the time constituted the management of the company. Nonetheless, the Committee believes that as Comptroller he should have instituted inquiries regarding the actual use of these corporate funds over which he had the responsibility of control.

Id. at 266 .

85. See E. Ginzberg \& E. Reilley, Effecting Change in Large Organizations 125-28 (1957).

1114 
sionmaking unit. Unlike Model I's profit-maximizing entity or Model III's self-aggrandizing executive, Model II's subcorporate unit is simply following preestablished procedures. Because Model II explains only how the decisionmaking unit acts and not why it acts, the model offers no guidance as to the relative effectiveness of fines, incarceration, publicity, or other penalties which might be imposed on entities or individuals.

The uncertainty is compounded by a second characteristic of Model II-its focus on a decisionmaking unit that is neither a corporation nor an individual. Considerably more investigation of the behavior of subcorporate units would be needed to ascertain the impact on them of penalties imposed on the corporation or certain of its employees. ${ }^{86}$ Until further research helps clarify these aspects of corporate decisionmaking, Model II statutes should probably authorize the full range of entity sanctions suggested by Model $I^{87}$ and the full range of employee sanctions suggested by Model III. ${ }^{88}$

Prosecutors faced with the decision of whether to seek an indictment or file a criminal information against a corporate decisionmaker often work with statutes manifesting no particular conception of how the proscribed corporate offense takes place. ${ }^{89}$ That Model II insights can be valuable to prosecutors even in the absence of Model II statutes is illustrated by the recent case of United States $v$. Park.90

86. The same point can be made with respect to individuals within the subcorporate unit. It would seem reasonable to presume that the personal goals of such individuals would be similar to those of individuals in other contexts. However, Professor Williamson stresses that at least the organizational goals of managers of subcorporate units may differ from those of corporate executives. O. Williamson, Corporate ConTrol AND Businsss Behavior 47-49 (1970). One might infer that penalizing the corporate entity would not have the same deterrent effect on a lawbreaking individual qua divisional manager as it would on a lawbreaking individual qua corporate executive. But more light must be shed on the difference Professor Williamson discerns before it can become the basis for imposing disparate criminal sanctions.

Courts are likely to await congressional initiative before imposing criminal liability directly on subcorporate units. See United States v. Gulf Oil Corp., 408 F. Supp. 450, 469-70 (W.D. Pa. 1975) (holding penal sanctions of Economic Stabilization Act of 1970, 12 U.S.C. $\$ 1904$ (Supp. IV 1974) (expired 1975), inapplicable to operating division of corporation in absence of express congressional intent to extend corporate liability in such way).

87. Pp. 1107.08 supra.

88. P. 1123 infra.

89. For examples, see the statutes cited notes $10 \& 29$ supra. Statutes drafted without decisionmaking models in mind may limit the applicability of a functional definition of criminal responsibility. See p. 1099 supra. For example, if specific intent were included as an element of a statutory offense, a corporate decisionmaker could not be held liable for failing to fulfill an affirmative duty to monitor SOPs. If specific intent is a traditional element of an offense, courts may find it a requisite of liability even in the absence of express statutory language. See Morissette v. United States, 342 U.S. 246, 263-73 (1952) (theft or knowing conversion of United States property). Such a finding is less likely with respect to regulatory offenses. See id. at 252.62.

90. 42I U.S. 658 (1975). This illustration applies equally to other decisionmaking 
There, the Government prosecuted John R. Park, the president and chief executive officer of Acme Markets, Inc. (Acme) for violating the Federal Food, Drug, and Cosmetic Act, ${ }^{91}$ which simply prohibits persons from "causing" acts that result in the adulteration of food or drugs being held for sale after shipment in interstate commerce. ${ }^{92}$

The Park prosecutor's task of evaluating the evidence and determining whether and whom to prosecute can be appreciated by reviewing the facts of the case. At the time of the prosecution, Acme, a national retail food chain headquartered in Philadelphia, had approximately 36,000 employees, 874 retail outlets, 12 general warehouses, and 4 special warehouses. One of the general warehouses was located in the corporation's Baltimore division. ${ }^{93}$

The Baltimore warehouse was inspected in late 1971 by two officials of the Food and Drug Administration (FDA). Present at the warehouse during all or part of the inspection were the vice president for the Baltimore division, the director of corporate distribution services, the chief sanitation engineer from corporate headquarters, the sanitation manager of the Baltimore division, the manager of the Baltimore warehouse, the superintendent of the warehouse, and several subordinate staff members. The FDA investigation revealed extensive rodent infestation. The inspectors delivered and explained to the warehouse manager a list of objectionable conditions. In addition, the FDA sent Park a regulatory letter in January 1972, advising him of the rodent infestation. A second inspection of the Baltimore warehouse took place in March 1972. An FDA official testified at the Park trial that "evidence of rodent activity" was found during the second inspection. ${ }^{94}$ In the criminal information he filed against Park and Acme, the prosecutor based his allegations of adulteration on the findings of the two inspections.

There was a third inspection that greatly influenced the prosecutor's decision to prosecute Park rather than any of the managerial employees

models. A model's utility is enhanced by, but not dependent on, the existence of statutes conceived with that particular model in mind.

91. 21 U.S.C. $\$ 331(\mathrm{k})(1970)$.

92. Section $301(k)$ of the Act, 21 U.S.C. $\$ 331(k)(1970)$, prohibits the following acts and the causing thereof:

The alteration, mutilation, destruction, obliteration, or removal of the whole or any part of the labeling of, or the doing of any other act with respect to, a food, drug, device, or cosmetic, if such act is done while such article is held for sale (whether or not the first sale) after shipment in interstate commerce and results in such article being adulterated or misbranded.

93. The facts of the case recited in this and subsequent paragraphs are drawn from the excerpts of the Park trial transcript reprinted in the Appendix at 16.71, United States v. Park, 421 U.S. 658 (1975) (filed jointly by petitioner and respondent) (on file with Yale Law Journal) [hereinafter cited as Joint Appendix]. For a summary of the facts brought out at trial, see 421 U.S. at $660-65$.

94. Joint Appendix, supra note 93, at 23. 
more closely connected with the company's Baltimore operations. It had taken place in an Acme warehouse in Philadelphia nearly 20 months prior to the first Baltimore inspection. The March 1970 inspection had revealed rodent infestation in the Philadelphia warehouse and had resulted in a letter being sent to Park in April 1970, notifying him of the serious problem.

The prosecutor sought to integrate the evidence into a theory of the case which bore a striking resemblance to the Organizational Process Model approach. In his cross-examination of Park, the prosecutor alluded to the inefficacy of the "system" of sanitation. ${ }^{95}$ In his closing argument, the prosecutor referred to the FDA letter to Park following the 1970 Philadelphia warehouse inspection as a warning given to Park that the "system wasn't working." the prosecutor argued to the jury, Park did not change the system. "[O]ther people were part of the system," he noted, "[but] the man at the top, the man who sets the system, . . . should be responsible." 97

The Park trial can be fruitfully analyzed in Model II terms. The prosecutor's contention was that the violation resulted from the operation of flawed SOPs. The evidence about the Philadelphia warehouse inspection was significant in two respects. First, it revealed that one or more sanitation SOPs were malfunctioning in divisions other than Baltimore. Second, it demonstrated that corporate management was notified of the ineffectiveness of the SOPs well before the malfunction for which Park was being prosecuted.

As Model II would suggest, the prosecution and the defense both focused during the trial on the power of Park to modify the SOPs and on his knowledge of their inadequacy by reason of the 1970 warning. The prosecutor introduced into evidence the corporate by-laws, indicating the overall authority of Park as chief executive officer. ${ }^{9 \mathrm{~s}}$ During cross-examination he drew from Park the admission that Park had read the 1970 letter from the FDA.99 Park's counsel, on the other hand, underscored the scope of Acme operations and the many levels of subordinates under Park who were authorized to oversee various corporate activities. ${ }^{100}$ Counsel for the defendant also claimed that Park had reasonably relied on his subordinates to handle the sanitation problem once it was brought to their attention. ${ }^{101}$ Apparently the jury

95. Id. at 55 .

96. Id. at 59-60.

97. Id.

98. Id. at $39-40$.

99. Id. at 51-52.

100. Id. at $32-38$.

101. Id. at 42-48, 55-56. 
was persuaded that Park had both the knowledge of the malfunctioning SOPs and the power to change them, for it returned a verdict of guilty. ${ }^{102}$

It is not clear from the Park trial transcript how thoroughly the prosecutor probed the Acme decisionmaking process. If the prosecutor had taken full advantage of the insights of Model II, he would have posed certain questions that would have helped identify how the SOP malfunction occurred: Which decisionmaking units in Acme (e.g., local warehouses, regional divisions, corporate headquarters) were involved with sanitation problems? What SOPs did these units have in order to foster the flow of information about sanitation problems? unannounced inspections by the corporation's chief sanitation engineer? periodic reports by warehouse staffs? circulation of FDA observation lists? What SOPs did Acme units have in order to generate policy alternatives about sanitation problems? a research and development program within the engineering division? a conference of sanitation managers from the various regional divisions? a special advisory group reporting to the president? ${ }^{103}$ What SOPs did Acme units have in order to implement alternative courses of action to resolve sanitation problems? directives from the president to the division managers? training programs for inventory workers? amendments to the company's employee manual? If some of these SOPs were nonexistent, how did the units involved with sanitation problems negotiate areas of responsibility and allocation of resources among themselves to mitigate uncertainty? ${ }^{104}$ These Model II questions attempt to locate criminal responsibility for the unlawful warehouse conditions. Answers to them would have helped the prosecutor to understand the decisionmaking process at Acme and, thereby, to determine whether the recurrent lawbreaking could be halted most effectively by prosecuting the chief executive officer of the corporation. ${ }^{105}$

102. Park was fined $\$ 50$ on each of five counts. 421 U.S. at 660,666 . For Park, more than the $\$ 250$ fine was at stake in the case, however, for his conviction will subject him to substantially greater penalties if he is convicted a second time under the Federal Food, Drug, and Cosmetic Act. 21 U.S.G. $\$ 333(a)$, (b) (1970).

103. If, for example, the prosecutor found that the Acme violation had occurred because the Baltimore division was using obsolete sanitation methods, the deterrent effect of criminal sanctions might be maximized by imposing them on those decisionmakers who promulgated the outmoded SOP or who failed to find an adequate alternative.

104. The import of this question is that the absence of SOPs may indicate that the subcorporate unit being scrutinized had negotiated away responsibility for warehouse sanitation. If in fact responsibility had been vested elsewhere, sanctions imposed on the decisionmaking unit under scrutiny would probably not deter future warehouse violations most effectively.

105. Ideally, appropriate imposition of criminal liability would result in the promulgation of new SOPS or the modification of existing ones to ensure lawful corporate actions. However, United States Attorneys often accept the guilty plea of the corporate 
However, these questions were neither expressly asked nor fully answered at the Park trial. It is not surprising, therefore, that the trial judge, despite the Model II tone of the trial presentations, relied in his jury instructions on a vague "responsible relation" standard inherited from another, arguably distinguishable case. ${ }^{106}$ Had the judge been aware of Model II, he would have been better prepared for the case presented in his courtroom and could have tailored his explanation of criminal liability to the specific facts of Park.

The judges and Justices who reviewed the Park trial on appeal might likewise have benefited from familiarity with Model II in resolving an evidentiary dispute in the case. Testimonial and documentary evidence about the 1970 FDA inspection of Acme's Philadelphia warehouse was admitted at trial over Park's objection that the introduction

entity in exchange for dismissal of prosecution against a corporate employee, "particularly where it appears that the [employee] has taken steps to correct the situation in respect of which the violation occurred." WorkingePAPERs, supra note 3, at 180. Although this practice may be a strategic prosecutorial response to the problem of inconsistent jury verdicts in corporate criminal trials, see note 27 supra, it may vitiate the impact of Model II liability on the quality of SOPs. For Model II stresses that "correcting" a rodent-infested warehouse is of limited value if the SOP resulting in the infestation is not also corrected.

This plea-bargaining practice may have an additional deleterious. effect. By giving corporate employees reason to believe that individual liability frequently does not result in individual sanctions, the practice may undermine the deterrent effect of corporate criminal law.

106. The trial judge in Park modeled his instructions on the holding in United States v. Dotterweich, 320 U.S. 277 (1943). Joseph Dotterweich was the president and general manager of Buffalo Pharmacal Company, Inc., a small drug firm with about $30 \mathrm{em}$ ployees, all under the direct supervision of Dotterweich. There was no evidence that Dotterweich personally directed the mislabeling that gave rise to the criminal charges against him. The evidence did establish, however, that all the firm's executive decisions were made by Dotterweich and that he was present while the shipment of adulterated goods was prepared. The Supreme Court held Dotterweich liable for a violation of the Federal Food, Drug, and Cosmetic Act on the ground that, although he had no "consciousness of wrongdoing," he had "a responsible share in the furtherance of the transaction [i.e., adulteration] which the statute outlaws." Id. at 284.

Similarly, the trial judge in Park told the jury that Park could be found guilty "even if he did not consciously do wrong," and even though he had not "personally participated in the situation," so long as the prosecutor proved beyond a reasonable doubt that Park had "a responsible relation to the situation." Joint Appendix, supra note 93, at 62. The court of appeals held this to be reversible error, for the obscurity of the terms "relation" and "situation" was sufficient to mislead the jury into thinking that a corporate president could be convicted solely by reason of his status as chief executive officer. 499 F.2d 839, 840-42 (4th Cir. 1974). The Supreme Court disagreed, holding that, "viewed as a whole and in the context of the trial," the instructions were an adequate guide to the jury. 421 U.S. at 675 . Three Justices dissented on this point. Id. at 678-83.

The trial judge could have made his instructions more precise and more relevant to the case at bar had he employed models to highlight the differences between the decisionmaking process at Acme and that at Buffalo Pharmacal. The latter process would seem to correspond to a factual pattern for which Model I is most applicable-a small firm that is apparently the alter ego of one individual. See p. 111 \& note 75 supra. The Acme process, in contrast, more closely parallels a factual pattern for which Model II is most applicable-a large firm facing a familiar problem involving many employees. See pp. 1120-21 infra. 
of evidence of alleged prior crimes was prejudicial. ${ }^{107}$ The Court of Appeals for the Fourth Circuit reversed Park's conviction, partly on that ground. ${ }^{10 s}$ The Supreme Court held that the evidence was admissible since it "served to rebut [Park's] defense that he had justifiably relied upon subordinates to handle sanitation matters." 109 However, the Supreme Court did not indicate whether such evidence was essential for Park's conviction. ${ }^{110}$ Had the Court taken a Model II approach to the case it would have held expressly that if Park were responsible for promulgation of Acme sanitation SOPs, then he would also be responsible for ensuring that information about their inadequacy reached him; ${ }^{111}$ prior government notice would therefore be superfluous to criminal liability.

In deciding whether a Model II approach is appropriate to a given offense or offender, judges, as well as prosecutors and legislators, should keep certain variables in mind. The variables-organizational structure, character of the problem for decision, and age of the subcorporate unit-are useful in that they suggest whether a corporation's decisionmaking process could have been effectively controlled only through the promulgation and implementation of SOPs. The variables do not establish that a corporation had SOPs for a particular problem; rather, they indicate whether the corporation should have had such SOPs. In such cases a Model II approach would provide a suitable framework for defining liability, for the violation would then be the result of either the presence of a malfunctioning or illegal SOP or the absence of an SOP that should have been promulgated.

SOPs routinize participation and thereby mitigate confusion and uncertainty among numerous decisionmaking employees. Therefore, an organizational structure that encourages the involvement of many people in a given decision should foster SOPs as a means of coordination. This is particularly so if the problem for decision (e.g., ensuring

107. Joint Appendix, supra note 93, at 50-56, $70-71$.

108. 499 F.2d at $842-43$.

109. 421 U.S. at 678 .

110. The Court noted that a defense of powerlessness to prevent or correct violations under the Fedcral Food, Drug, and Cosmetic Act can be raised by corporate employee. Id. at 673. But it did not mention as a defense the lack of prior notification of violations, despite the prosecutor's emphasis on the 1970 letter at trial.

111. The Court concluded that Park had "not only a positive duty to seck out and remedy violations when they occur but also, and primarily, a duty to implement measures that will insurc that violations will not occur." Id. at 672 . The quoted holding is unexceptionable as a statement of a Model II affirmative duty. However, whether that duty should have been imposed on Park is open to question, for the Court did not examine the Acme decisionmaking process to determine who most effectively could have prevented recurrent malfunctioning of the particular SOP that gave vise to the unsanitary warehouse conditions. 
sanitation of warehouses) is one that as a matter of course consumes the time of many people within the relevant subcorporate unit. Familiarity with the particular problem should also encourage the promulgation of SOPs and suggest the applicability of Model II, because the more ordinary the problem facing the subcorporate unit, the easier and more advantageous it is to have a regular way of resolving it. Finally, the older the subcorporate unit, the more it should, and is likely to, depend on SOPs, both because SOPs have had time to emerge, whether by habit or directive, and because corporate managers usually have become disposed to stability and certainty. ${ }^{112}$ Model II is most likely to apply to corporate lawbreaking that arises from routine corporate operations. Pollution offenses, adulteration, underweighting, illegal sales techniques-these are typical of crimes that one would expect to be deterred by legal policymaking guided by Model II.

\section{The Bureaucratic Politics Model}

The Model III conception of the decisionmaking process implies that responsibility for corporate crime must be defined in terms of the actions of individuals. Unlike Model I, Model III focuses on the interests and influences of individuals, not entities. Unlike Model II, Model III conceives of these individuals as conscious proponents of corporate action rather than as constrained followers of preselected procedures. From this view Model III seems especially favorable to theories of individual liability.

The implications of Model III suggest that criminal liability in the corporate context must be two-pronged if the law is to achieve maximum deterrent effect. One component should be directed at those who participate in lawbreaking, the other at certain decisionmakers who do not participate. With respect to the former, culpable participation in bargaining games should include acquiescence in an unlawful decision as well as advocacy of it. ${ }^{113}$ The guiding principle should be that every corporate decisionmaker has an affirmative duty to purge a course of action of its illegal aspects before acquiescing in it. ${ }^{114}$

This first component of Model III liability of course applies to

112. Sce A. Dowss, supra notc 48 , at $18-20,96-100$ (contending that as bureaucratic units age they become more inert and rule-bound, partly because management becomes increasingly dominated by "conservers" rather than "zealots").

113. Advocacy does not always take the form of explicit statements of support. Approbation of a particular course of action can be signaled in various ways. For example, for many years certain Gencral Electric managers litcrally winked at reports of collusive price fixing between GE and its competitors. J. HrrLiNG, supra note 83 , at $40-42$.

114. Cf. 12 U.S.C. $\$ 622$ (1970) (each director and officer who assented to violation of Federal Reserve Act personally liable for all damages sustaincd by corporation as result). 
high-level corporate officials-those who are most active and influential in making bargains. But Model III also implies that middle-level managers should be liable for illegal corporate actions under certain circumstances. Model III recognizes the leeway granted to those carrying out corporate decisions by reason of the imprecision characteristic of consensual mandates. Therefore, liability should be imposed on those who use illegal means to implement lawful decisions ${ }^{115}$ and on those who fail to resist the implementation of unlawful decisions. ${ }^{110}$ The conception of corporate action presented by Model III suggests that only by imposing liability at the lower levels of the corporate power structure as well as at the higher levels can corporate lawbreaking be controlled. ${ }^{117}$

The objective of the second component of Model III liability is to ensure that potentially influential players do not insulate themselves from a consensus that, either in formulation or in implementation, is tainted by illegality. ${ }^{118}$ The instrument is the imposition of an affirmative duty on such players to ensure the lawfulness of the political resultants emerging from their areas of responsibility. ${ }^{119}$ Responsibility

115. For cxample, liability should attach to those who take part in a price-fixing conspiracy as a way of implementing a decision urging all corporate units to reducc price instability.

116. Such liability would be premised on actual or constructive knowledge of the illegal implementation. An example of actual knowledge is the knowledge of the participants in the two-tiered price-fixing conspiracy within the electrical industry during the 1950s. High-level officials from leading manufacturers (generally vice presidents and divisional or departmental managers) met several times a year to establish basic pricing policies, and a group of middle-level managers (generally assistant general managers, marketing managers, and sales managers) met every two or three weeks to discuss price lists for specific bids. J. HeRI.ING, supra note 83, at 91, 102-06. An example of constructive knowledge is the knowledge of certain employees who delivered Gulf's corporate contributions to political figures. Deliveries were accomplished by staff assistants of the chief lobbyist or by regional vice presidents, often under circumstances that should have apprised the messengers of the character of the enterprise. Gulf Committee Report, supra note 84 , at $66-67,76-82$.

117. Recognition of the vulnerable position of lower-level employees who antagonize their superiors by objecting to illegal corporate practices has generated a number of proposals to ensure their protection. See WhIstle Blowing: THE REPORT of the CoNference on Professional Responsibility 3-11, 25-33, 183-91 (R. Nader, P. Petkas \& K. Blackwell eds. 1972); Blumberg, Corporate Responsibility and the Employee's Duty of Loyally and Obedience, 24 OkLA. L. REv. 279, 307-18 (1971).

118. Often, top corporate executives claim ignorance of lawbreaking in which their subordinates have been heavily involved. For instance, the individuals who held the positions of comptroller, general counsel, president, and chairman of the board of Gulf Oil Corporation during the time that over $\$ 4.5$ million in corporate funds were being channeled illegally to American politicians almost invariably denied any knowledge of unlawful corporate contributions. Gulf Committee Report, supra note 84 , at 4, 228.40, 242-66, 269-79. Comparably important officials of Westinghouse Electric Corporation asserted that they were unaware of the massive price-fixing conspiracy in the electrical equipment industry until indictments were handed down against their firm and their managerial subordinates. J. HerLING, supra note 83 , at 117-22, 133-35.

119. Note that the proposed revisions of Title 18, described at note 3 supra, include a provision creating employee liability for reckless default in supervising the conduct of 
need not-indeed, according to Model III, should not-be equated with official authority. Rather, all individuals heavily involved in a particular problem area-regardless of their official status-could be required to report their identity by signing permit applications, regulatory reports, or other required documents. ${ }^{120}$ Alternatively, legislators could authorize use of investigative powers to gather sufficient information to discover which corporate decisionmakers have potential influence in a particular game or class of games. ${ }^{121}$

By enacting statutes embodying these standards of liability, legislators would, in Model III terms, transform the rules of the corporate bargaining game and thereby shape the conduct of corporate decisionmakers. ${ }^{122}$ Model III implies that the most effective sanctions for violating the rules would be those that diminish the influence of lawbreaking players. Such sanctions not only would increase the relative influence of law-abiding players but also would threaten potential lawbreakers with deprivation of status, wealth, and other values that derive from influence. Fines, publicity, incarceration, exclusion from office-all these would reduce, to varying degrees, the influence of the penalized official and indicate that nonparticipation may result in similar penalties. ${ }^{123}$ Sanctions against the corporate entity might also be

activities that result in a violation and over which the employee has supervisory responsibilities. See, e.g., S. 1, 94th Cong., Ist Sess. $\$ 403$ (c) (1975), quoted at note 8 supra. It is not clear whether "supervisory responsibilities" are limited to those officially authorized by the corporation.

120. Statutes of this kind are useful under Models I and II as well, see pp. 1106, I113 sttpra, though their function under Model III corresponds much more closely to that under Model II than to that under Model I, see note 80 supra. However, the scope of the Model III reporting requirement would be broader than that of Model II, because Model III stresses the importance of identifying all those who have potential influence in a particular game.

121. The Federal Trade Commission Act, 15 U.S.C. $\$ 46(b)$ (1970), suggests the scope of authority that would be necessary to clicit the details of intracorporate behavior required by Model III. The Act authorizes the Commission to require corporations to file with it information about their "organization, . . . conduct, practices, [and] management." The Commission may prescribe that the information be given under oath. Information obtained pursuant to such authority could supplement that arailable from corporate organization charts, which are not entirely satisfactory for Model III analysis of the decisionmaking process. See pp. $1124-25$ \& note 127 infra.

122. New criminal statutes are not, of course, the only means of altering the rules of the game. Professor Sterenson considers a number of ways of changing the rules, such as including labor or shareholder representatives on the board of directors, establishing a visiting committec of private and public officials to inquire into and report on the activities of the largest corporations, and cnacting a special "Bill of Rights" to guard individuals against abuses of corporate power. See Stevenson, Corporations and Social Responsibility: In Search of the Corporate Soul, 42 Geo. Wash. L. Rev. 709, 728-36 (1974). Another means of altering the rules of the game is federal chartering of corporations. See generally Symposium-Federal Chartering of Corporations, 61 GEo. L.J. 71 (1972).

123. The impact of fincs on individual decisionmakers can be dissipated by corporate insurance plans. Some state statutes permit corporations to indemnify corporate employees for criminal fincs under ccrtain circumstances. Knepper, Officers and Directors: 
desirable to the extent that they constrain corporate employees. ${ }^{124}$ But this seems to be a blunt instrument, for it is unclear which employees would be most penalized by such sanctions.

For prosecutors, Model III provides a number of useful insights. In contrast to Model I's focus on costs and benefits and Model II's focus on procedures, Model III urges the prosecutor to consider the personalities and personal concerns ${ }^{125}$ of corporate decisionmakers in gathering evidence about how a violation took place. Model III alerts the prosecutor to the important role of misperceptions, ${ }^{126}$ the inexact correspondence between official positions and key players, ${ }^{127}$ and the

Indemnification and Liability Insurance-An Update, 30 Bus. LAw 951, 957 (1975). By shifting the loss from employee to corporation, such indemnification in effect transforms Model II and Model III sanctions into Model I sanctions.

The possibility of excluding convicted corporate officials from office is considered in Working Papers, supra note 3, at 195. Such a sanction was recommended in Final REPORT, supra note 3 , at 306-07, and would be authorized by H.R. 333, 94th Cong., 1st Sess. $\S 3502$ (1975). However, it was not included in H.R. 10850, 94th Cong., Ist Sess. (1975), or H.R. 3907, 94th Cong., 1st Sess. (1975), and it failed to survive beyond S. 1, 93d Cong., lst Sess. (1973), a predecessor of the current Senate bill. See 1974 Hearings, supra note 3, at 7770-71 (report of Association of the Bar of the City of New York criticizing provision in early version of S. 1). Exclusion from office is already authorized as a sanction against union members by the Labor-Management Reporting and Disclosure Act of 1959, 29 U.S.C. $\$ 504$ (1970), and a similar state statute was upheld by the Supreme Court. De Veau v. Braisted, 363 U.S. 144 (1960). The Court has intimated that exclusion from office might be an appropriate penalty for corporate managers guilty of predatory practices. United States v. Grinnell Corp., 384 U.S. 563, 579 (1966) (dictum).

124. The impact of entity sanctions, particularly fines, on individual decisionmakers is questioned in Comment, supra note 1 , at 292-93. On the other hand, Stevenson, stipra note 122 , at 724-28, discusses the importance of corporate image to managers and sug. gests ways of using that leverage as a sanction to influence corporate conduct. One of Professor Stevenson's suggestions is modification of disclosure requirements. In this light a recent Securities and Exchange Commission (SEC) initiative to protect investors may have wider ramifications for the control of corporate conduct. The SEC amended its rules to require corporations issuing securities to disclose any environmental regulations that may require them to make significant capital outlays and any civil rights litigation that may result in serious sanctions. Securities Act Release No. 5170, 36 Fed. Reg. 13989 (1971), amended in part, Securities Act Release No. 5386, 38 Fed. Reg. 12100 (1973). Similarly, Securities Act Release No. 5466, 39 Fed. Reg. 10237 (1974), requires that corporations disclose in their prospectuses and proxy statements any convictions for illegal campaign contributions as well as any pleas of guilty or nolo contendere to charges of such illegalities.

125. A former general counsel of Gulf Oil Corporation explained that his office did not investigate his own suspicions about Gulf's political contributions because one of the chief executive officer's "pet peeves was lawyers who got in to the business or policy aspects of the company. He wanted business executives to make business decisions." Gulf Committee Report, supra note 84 , at 233 .

126. A Gulf comptroller told the Special Review Committee that his suspicions about the source of the funds used by Gulf's chief lobbyist led him to discuss the matter with the general counsel. However, he never informed the general counsel that the funds were being funneled through an account in a Bahamas bank, later recalling, "[I]n my mind I thought [he] already knew it." Id. at 228 . When questioned by the SEC, the general counsel denied knowledge of this fact. Id. at 231.

127. Corporate decisionmakers without high official status may be prime movers in certain bargaining games, while officially authoritative exccutives may be circumvented in others. Compare id, at 226 (details of illegal political contributions arranged by small 
existence of disagreement behind most corporate decisions. ${ }^{128}$

To penetrate the corporate façade in, for example, a case of corporate campaign contributions, a prosecutor applying Model III would ask such questions as: How was bargaining about the corporation's political leverage structured within the corporation? Was it considered a problem solely for the public affairs office or one for each decisionmaking unit to handle in its own way? a matter for high-level informal contacts or one requiring multiple official clearances? an issue arising only when critical legislation was pending or one demanding continuing vigilance? Which players in which positions were centrally involved? certain lobbyists, executive vice presidents, special assistants to the chairman of the board, managers of politically sensitive divisions? What bargaining chips inhered in the positions of each of these central players? Did, for example, the organizational structure give a certain position unusual power with respect to either the problem of political leverage or the central players involved? What were the prior commitments, sense of priorities, time constraints, and intracorporate stature of each of the central players, and who were the bureaucratic allies of each? In short, apart from his position, how hard was each of these players likely to have played this particular bargaining game, and how much influence would each probably have had? These Model III questions probe the corporation's decisionmaking process in an effort to illuminate the way in which bargaining over corporate campaign contributions would have taken place. By conducting his investigation with these questions in mind, the prosecutor could gather evidence pertinent to Model III and determine whether this evidence would sustain a Model III case against one or more decisionmakers. ${ }^{129}$

However, both the insights provided by Model III and the questions

group of Gulf's senior executives-chairman of the board, general counsel, and a vice president-along with lobbyist who held no officer position) with id, at 32-33, 235 (members of group that arranged Gulf contributions scheme withheld knowledge of it from "Boy Scouts," a reference to three high officials, including one who would shortly become president of Gulf) and J. HerLING, stupra note 83, at 225, 231 (sales manager of General Electric division was told by GE vice president not to inform general manager of division about ongoing meetings with competitors because general manager did not "understand these things").

128. The varying degrees of dissension from a particular course of action are illustrated by the Gulf political contribution scheme, which caused discomfort for at least one corporate officer and fisticuffs between two others. Gulf Committee Report, supra note 84 , at $229-30,44$.

129. The current statute prohibiting corporate campaign contributions, Federal Election Campaign Act, 2 U.S.C.A. $\$ 441 \mathrm{~b}(\mathrm{a})$ (Scpt. 1976 Pamphlet), limits the criminal liability of corporate decisionmakers to those who "consent to any contribution or expenditure by [their] corporation." Therefore, courts may be reluctant to penalize potentially influential employees for nonparticipation, as recommended by Model III. This is an instance in which legislative action may be necessary to enable prosecutors and judges to make full use of Model III's implications. 
suggested by it imply that a Model III prosecution may be difficult. According to Model III, actual responsibility need not correspond to official authority, and the fluidity of the bargaining process alters the identity of key players from game to game. Since the perimeters of criminal responsibility under Model III are blurred, the evidentiary requirements for a successful Model III prosecution are onerous.

This burden could be mitigated by retreating from the two-pronged strategy outlined above and restricting Model III liability to those players who actively participate in the bargaining that results in a corporate offense. Decisionmakers who do not participate, for whatever reason, would not be liable. But such an emasculation of the second component of the Model III liability strategy could well undermine the first component as well. The more influential players might keep their distance from the bargaining, perhaps exercising control through discreet, undocumented suggestions to their participating subordinates. In this way, those nonparticipants who could have prevented corporate lawbreaking would escape criminal liability.

Therefore, it would be preferable to expand the scope of Model III liability for nonparticipants rather than eliminate it. The affirmative duty to ensure the lawfulness of political resultants should be imposed on all those whose official status or actual authority qualifies them as potentially influential players in the game in question. The second component of Model III liability thus would allow wide prosecutorial discretion in the choice of which players to prosecute for a corporate offense.

It would be the obligation of trial and appellate judges to ensure that this prosecutorial discretion is not abused. In a Model III case, a judge would normally find unacceptable a middle-level manager's defense that he was "only following orders," unless the manager could also demonstrate that he could not reasonably have known that his obedience involved such illegalities as bribery or fraud. On the other hand, a judge would understand a top executive's argument that the terms of a decision made by the upper echelon of the corporation's management had been distorted without his knowledge by subordinates charged with implementing it. However, this defense would not avail the executive if his actual influence in the bargaining belied his claim of ignorance or if his potential influence imposed on him an affirmative duty to participate. Finally, if a player sought vigorously to influence the trend of the game in a law-abiding direction, but was systematically excluded from the game or deluded about its lawbreaking character by superior or subordinate players, he would have an 
affirmative defense to his alleged failure to perform his duty of participation.

Despite the availability of affirmative defenses, the second prong of Model III liability would place considerable pressure on corporate decisionmakers. Indeed, the breadth of Model III liability might well encourage managers to reduce the fluidity of their decisionmaking process through routinization. For the purpose of controlling lawbreaking, routinization offers a number of advantages over bargaining. It standardizes the roles of key players from game to game, facilitating oversight by superior players. It discourages circumvention, since a decisionmaker disciplined by a set procedure is less easily dislodged from the flow of decision than is a decisionmaker with no established role. Finally, routinization facilitates the legal policymaker's task of identifying responsible decisionmakers and thereby imposing liability where it will have the greatest deterrent effect.

Thus, an important byproduct of Model III liability, particularly the liability of nonparticipants, may be to restructure the corporate decisionmaking process along Model II lines. ${ }^{130}$ Influential players would, in effect, routinize themselves in or out of various games, resolving the issue of whether they should have become involved in any given decision. ${ }^{131}$

Not all decisionmaking can be routinized, however, and bureaucratic politics is an inherent facet of the corporate form. Therefore, under certain circumstances, legal policymakers would be wise to consider the applicability of Model III. The decisionmaking variables identified in the discussion of Models $\mathrm{I}$ and $\mathrm{II}^{132}$ are useful in evaluating the relevance of Model III as well.

130. Cf. 1972 Hearings, supra note 2, at pt. III, subpt. D, 3014 (statement of Mark Silbergeld, Public Interest Research Group, supporting proposed employee liability for default of supervisory responsibilities: "[It is] likely . . . that organizations, in response to [such liability], will more clearly define subject matter responsibility, leading to precisely the kind of restructured deterrence which sound law would stimulate.")

131. Legislators can encourage the shift from Model III to Model II decisionmaking by enacting statutes that impose broad supervisory duties on decisionmakers but expressly allow fulfillment of such duties through SOPs. A useful guide is 15 U.S.C. $\$ 780$ (b)(5)(E) (1970), which authorizes the SEC to apply civil sanctions to over-the-counter brokers and dealers who fail "reasonably to supervise" individuals supposedly under their supcrvision, where such failure results in a violation of the securities laws. However, no person shall be deemed to have failed reasonably to supervise any person, if -

(i) there have been established procedures, and a system for applying such procedures, which would reasonably be expected to prevent and detect, insofar as practicable, any such violation by such other person, and

(ii) such person has reasonably discharged the duties and obligations incumbent upon him by reason of such procedures and system without reasonable cause to believe that such procedures and system were not being complied with.

132. See pp. 1110-11 \& notes 73-76, pp. 1120-21 \& note 112 supra. 
Generally, corporate bargaining intensifies when the market structure does not press managers to achieve competitive efficiency. ${ }^{13: 3}$ Furthermore, organizational structure that encourages the involvement of numerous hierarchical levels in a given corporate decision fosters bureaucratic politics. For example, a corporation organized according to functional divisions ${ }^{134}$ (e.g., research and development, marketing, finance, production) tends to engage the hierarchies of each division in the resolution of a particular problem. ${ }^{135}$ The result is more conflict among corporate units and managers; ultimate corporate actions are more likely to be political resultants.

Just as Model II would be most insightful where a subcorporate unit is old or where the issue for decision is familiar, Model III would have greatest explanatory power where a unit or individual has recently assumed authority for a given task or where the decision concerns sensitive or controversial matters. Thus, a Model III approach should be considered with respect to those corporate violations arising shortly after a corporate merger, those related to recently issued regulations, and those concerning the firm's competitive or political environment (e.g., price fixing, bribery).

\section{Conclusion}

The three models employed in this Note are paradigmatic, not Procrustean. In applying them to actual instances of corporate lawbreaking, the task is not to reduce the infinite gradations of corporate decisionmaking to three inflexible types. Rather, the three models, as well as eclectic alternatives, should be employed to gain insights into the diversity and complexity of the decisionmaking process. ${ }^{136}$ The

133. See O. Williamson, supra note 51, at 170-72 (suggesting that deviation from model comparable to Model $\mathrm{I}$ is most likely in monopolistic markets).

134. Functional divisions are different from the operating divisions mentioned at p. 1111 supra. Each functional division deals with a complex of tasks, such as marketing or manufacturing, for the entire corporate entity. Each operating division, such as Chevrolet, performs all marketing, manufacturing, and other functional tasks for its own product.

135. See O. Williamson, supra note 54, at 133-35 (contending that such organizational structure, which Professor Williamson terms "unitary form" or "U-form," results in "control loss" and dominance of other-than-profit objectives because of interplay among hierarchies).

136. The usefulness of decisionmaking models is not limited to the problem of corporate crime. Legal control of public organizations, such as metropolitan police departments, is another broad area to which the models might productively be applied. Compare Rizzo v. Goode, 423 U.S. 362, 373-77 (1976) (overturning injunctive relief granted against city and police officials based on alleged misconduct by subordinate policemen) with id. at 384-87 (dissenting opinion). The models might also shed light on narrower problems of law, such as judicial review of allegedly prejudiced administrative 
primary insight provided by the models is that the character of corporate decisionmaking varies widely: at every level of legal policymaking it must be regarded as an issue of fact. By providing guidance for the discovery and interpretation of facts about corporate decisionmaking, the models make their most valuable contribution.

That contribution has been sketched in preliminary fashion in this Note. By conceptualizing corporate decisionmaking, the models alert legal policymakers to the relevance of particular facts and suggest deterrence strategies consistent with the conceptions supported by the facts. Collectively, the models imply that only under limited circumstances can effective deterrence be achieved by penalizing the corporate entity rather than corporate employees. For most circumstances, the models recommend the creation of affirmative duties for certain individuals to monitor corporate procedures and to participate in corporate bargaining.

If the imposition of liability is rooted in systematic analysis of facts, the concept of criminal responsibility can reflect the variations in corporate decisionmaking without becoming amorphous. By encouraging such systematic analysis, the models can enhance the law's capacity to define criminal responsibility with sufficient clarity to guide both legal policymakers and corporate decisionmakers.

action. Cf. W. GellhokN \& C. Byse, Administrative Law 957-58 (6th ed. 1974) (referring to instances where one part of an agency conducts a hearing to consider the validity of charges lodged by another part of an agency: "How far should the courts go . . . in regarding an administrative agency as though all of its parts were moved by a single brain, instead of as an aggregation whose, moves are responsive to many minds, often without awareness of movements dictated by yet other minds?"). 